$A D$

(Leave blank)

Award Number: W81XWH-10-1-0552

)

TITLE: The Role of BRCA1 in Lethal Prostate Cancer

PRINCIPAL INVESTIGATOR: Lorelei A. Mucci, ScD

CONTRACTING ORGANIZATION:

Brigham and Women's Hospital Inc.

Boston, MA 02115-6110

REPORT DATE: August 2013

TYPE OF REPORT: Annual

PREPARED FOR: U.S. Army Medical Research and Materiel Command Fort Detrick, Maryland 21702-5012

DISTRIBUTION STATEMENT:

Approved for public release; distribution unlimited

The views, opinions and/or findings contained in this report are those of the author(s) and should not be construed as an official Department of the Army position, policy or decision unless so designated by other documentation. 
Public reporting burden for this collection of information is estimated to average 1 hour per response, including the time for reviewing instructions, searching existing data sources, gathering and maintaining the data needed, and completing and reviewing this collection of information. Send comments regarding this burden estimate or any other aspect of this collection of information, including suggestions for reducing this burden to Department of Defense, Washington Headquarters Services, Directorate for Information Operations and Reports (0704-0188), 1215 Jefferson Davis Highway, Suite 1204, Arlington, VA 222024302. Respondents should be aware that notwithstanding any other provision of law, no person shall be subject to any penalty for failing to comply with a collection of information if it does not display a currently

\begin{tabular}{l|l|l|l} 
valid OMB control number. PLEASE DO NOT RETURN YOUR FORM TO THE ABOVE ADDRESS. \\
\begin{tabular}{l|l|l|l} 
1. REPORT DATE (DD-MM- $Y Y Y Y)$ & 2. REPORT TYPE & 3. DATES COVERED (FrOm - TO)
\end{tabular}
\end{tabular}

\begin{tabular}{l|l} 
August-2013 & Annual \\
\hline 4. ThIEE AND SuBTITEE
\end{tabular}

4. TITLE AND SUBTITLE

Annual

The Role of BRCA1 in Lethal Prostate Cancer 01 August $2012-31$ July 2013 5a. CONTRACT NUMBER

5b. GRANT NUMBER

W81XW-10-1-0552

5c. PROGRAM ELEMENT NUMBER

6. AUTHOR(S)

Lorelei A. Mucci lorelei.mucci@channing.harvard.edu

5d. PROJECT NUMBER

5e. TASK NUMBER

5f. WORK UNIT NUMBER

8. PERFORMING ORGANIZATION REPORT NUMBER

Brigham and Women's

Hospital Inc.

Boston, MA 02115-6110

9. SPONSORING / MONITORING AGENCY NAME(S) AND ADDRESS(ES)

U.S. Army Medical Research

And Material Command

Fort Detrick, Maryland

21702-5012

S) AND ADDRESS(ES)

\section{DISTRIBUTION / AVAILABILITY STATEMENT}

Approved for public release; distribution unlimited.

\section{SUPPLEMENTARY NOTES}

\section{ABSTRACT}

BRCA1 is involved in DNA maintenance and repair as well as in cell cycle control. We hypothesized that activation of BRCAl in prostate tumors is a consequence of an increased proliferation rate as a compensatory mechanism of tumor cells to allow DNA repair in highly replicating cells. As such, tumor expression of BRCA1 is a marker of lethal prostate cancer. In a recently submitted manuscript, we confirmed our previous results that BRCA1 positive tumors are characterized by an aggressive, lethal phenotype and increased indices of apoptosis and cell proliferation in a large cohort of men with prostate cancer from the Health Professionals Follow-up study. Moreover, in preliminary analyses we see that genetic variation in BRCA1 captured by tagging SNPs is associated with increased risk of lethal cancer. We plan to correlate BRCA1 status in tumors with expression of cell cycle regulators, p27 and p21. This project's goals are to identify biomarkers of progression by examining BRCA1 tumor status and cancer mortality, as well as to understand aspects of tumor biology associated with BRCA1.

\section{SUBJECT TERMS}

Prostate cancer, lethal, BRCAl, cell cycle

\begin{tabular}{|c|c|c|c|c|c|}
\hline \multicolumn{3}{|c|}{ 16. SECURITY CLASSIFICATION OF: } & $\begin{array}{l}\text { 17. LIMITATION } \\
\text { OF ABSTRACT } \\
\text { UU }\end{array}$ & $\begin{array}{l}\text { 18. NUMBER } \\
\text { OF PAGES } \\
45\end{array}$ & $\begin{array}{l}\text { 19a. NAME OF RESPONSIBLE PERSON } \\
\text { USAMRMC } \\
\text { 19b. TELEPHONE NUMBER (include area } \\
\text { code) }\end{array}$ \\
\hline
\end{tabular}




\section{$\underline{\text { Page(s) }}$}

Introduction ........................................................................... 4

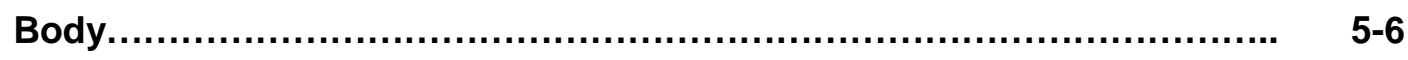

Key Research Accomplishments............................................. $\quad$ 7-8

Reportable Outcomes.................................................................. 9

Conclusion ......................................................................... 10

References......................................................................... 11

Supporting Data............................................................. 12-18

List of Appendices........................................................... 19

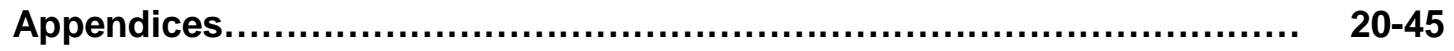




\section{INTRODUCTION}

BRCA1 (breast cancer 1, early onset) plays diverse functions including DNA maintenance and repair $^{1-3}$ as well as cell cycle control, such that $B R C A 1$ induced arrest at different check-points of the cell-cycle to allow the necessary time required for DNA repair. ${ }^{4-6}$ Few studies have examined tumor expression of BRCA1 as a biomarker of lethal prostate cancer. Inherited mutations in BRCA1, usually resulting in non-functional, truncated proteins, have been implicated in substantially increased risk in breast and ovarian cancer ${ }^{7-9}$ Accumulating evidence also points to $B R C A 1$ germline mutations causing increased prostate cancer risk in specific study populations. ${ }^{10,11}$ While the associations of germ-line mutations in BRCA1 on prostate cancer susceptibility have been examined in some detail, no study has examined germline mutations or common polymorphisms in relation to lethal prostate cancer, nor whether germline variation in $B R C A 1$ could influence protein tumor expression. Our hypothesis is that activation of $B R C A 1$ in a subset of prostate tumors is a direct consequence of the increased proliferation rate. This activation is a compensatory mechanism of the tumor cells in the attempt to allow DNA repair in rapidly replicating cells. If confirmed, our preliminary findings suggest $B R C A 1$ protein expression could be an important biomarker of lethal prostate cancer and help guide therapeutic decisions. In addition, these results will help advance our understanding the role of $B R C A 1$ in cell cycle control, and perhaps lead to identification of potential targets for new anticancer agents. The objective of the proposed study is to characterize the role of $B R C A 1$, both at the tumor and DNA level, in prostate cancer progression. Specifically, we hypothesize that prostate tumors positive for $B R C A 1$ are characterized by a rapidly lethal phenotype, and that this association is due to a "last chance" compensatory mechanism by cells to overcome the highly proliferative nature of a subset of tumors. Moreover, we hypothesize that prostate cancer cases with $B R C A 1$ mutations or specific genetic variants are at increased risk of lethal prostate cancer, and that part of the association may be acting through regulation of $B R C A 1$ expression in tumors. 


\section{BODY}

\section{Specific Aim 1: BRCA1 tumor expression and lethal prostate cancer}

We characterized BRCA1 tumor status in prostate cancer using immunohistochemistry on tumor tissue microarrays to evaluate expression of the BRCA1 protein. This was completed for 1,300 men with prostate cancer. Moreover, we proposed to characterize the extent of tumor proliferation and two markers of cell cycle progression (p21 and p27). We have now completed immunohistochemical staining and evaluation for the markers BRCA1 and ki67 on six tumor tissue microarrays for the Health Professionals Follow-up Study (HPFS) (as shown in Supporting Data, Figure I). We have further stained for p21 and have begun the quantitative image analysis of expression on the 2,000 tumor tissue microarray cores. We have achieved our major benchmarks for Tasks 1 and 2 .

We had previously completed the clinical review of the tumor tissue cohort with follow-up in the last funding period. For this year, we continue to follow the cohort of patients for development of metastatic disease and cancer/all cause mortality. The endpoints committee has completed the review for cause of death, and we have finalized the abstraction of data on metastases and additional treatment information. We have a finalized a SAS dataset for all of the men with prostate cancer in the cohort. Thus, we have completed Task 3 of this aim.

We have now completed the statistical analyses of BRCA1 protein expression and lethal prostate cancer in the Health Professionals Follow-up Study. The manuscript submitted to Molecular Cancer Research appears as Appendix 1. In line with our findings in the Physicians' Health Study ${ }^{1}$, we found immunohistochemical staining was positive for BRCA1 protein in a subset of prostate cancer patients (10 percent). There was a strong correlation between BRCA1 expression and Gleason grade, with BRCA1-positive tumors being of higher grade than BRCA1negative tumors $\left(p_{\text {trend }}=0.01\right.$, Supporting Data, Table I). Moreover, we found that prostate tumors expressing BRCA1 also exhibited a higher proliferative index as measured by Ki67 expression ( $p_{\text {trend }}=0.005$ ). During a median follow-up time of 14 years, 59 men ( 11 percent) in the BRCA1-negative group and 15 men (25 percent) in the BRCA1-positive group developed metastases or died of prostate cancer-related causes. On unadjusted analysis, there was a strong positive association between BRCA1 protein expression and risk of lethal prostate cancer (HR 2.40, 95\% Cl 1.36-4.23, $p=0.003$, Supporting Data, Table II). After adjusting for age at diagnosis and Gleason score, there remained a higher risk of lethal prostate cancer among men with BRCA1-positive tumors (HR 1.76, 95\% Cl 0.99-3.11, $p=0.053$ ). This association was not substantially attenuated after adjusting for ki67, suggesting a pathway of BRCA1 expression independent of cell cycle regulation. These data, in combination with results from the Physicians' Health Study, suggest that prostate tumors expressing BRCA1 protein are characterized by dedifferentiation and a high proliferative index, and BRCA 1 expression may be an independent predictor of prostate cancer progression. We have made substantial progress on this task as well as the aim overall.

\section{Specific Aim 2: Germline mutations and polymorphisms in BRCA1 and lethal prostate cancer}

On November 16, 2011, we received approval from the US Army Prostate Cancer program to change the scope of Aim 2. Given the low frequency of genetic mutations in BRCA1 in a nonfamilial cancer population, we suggested to revise the original aim as follows: 1-) Examine common gene variants in BRCA1 and risk of aggressive prostate cancer using existing genotyping data from a genome wide associate study scan; 2-) Integrate mRNA and microRNA 
data together with the BRCA1 protein expression data to understand mechanisms and additional pathways associated with the expression of BRCA1 at the protein level.

For the first part of the aim, we evaluated existing data from a genome wide association study among 630 prostate cancer cases in the Physicians' Health Study that were genotyped using an Affymetrix platform ${ }^{2}$. We studied six single nucleotide polymorphisms (SNPs) in BRCA1 in relation to cancer-specific mortality. We found all six BRCA1 SNPs were positively associated with risk of lethal prostate cancer during follow-up (Odds Ratios 1.29-1.34, p-trend .02-.04). The SNPs from the Affymetrix platform are in strong linkage disequilibrium, such that one SNP characterizes the other SNPs. We have initiated kernel machine based algorithms to more comprehensively analyze the pathway. Moreover, we have received additional data on common genetic variation in BRCA1 from 550 prostate cancer cases and age-matched controls who are part of an $\mathrm{NCl}$ funded genome wide scan of aggressive prostate cancer. The prostate cancer cases include men diagnosed with advanced stage (T3 or higher) or high grade (Gleason 8 or higher) cancers.

In the past year, we have further genotyped common variation in BRCA1 among 1400 cases from the Health Professionals Follow-up Study. Using the Tagger algorithm implemented in the Haploview program, we identified 6 linkage disequilibrium tagging single nucleotide polymorphisms (SNPs) to capture variation with $\mathrm{R}^{2}>0.8$ within $B R C A 1$ and 10 kilobases up and downstream. We have created a dataset to integrate the genotyping data with protein expression of BRCA1 (immunohistochemistry) and the tumor mRNA expression of BRCA1. We are currently analyzing the data to assess the association between the SNPs and prostate cancer survival. We will also assess if the SNPs are related to mRNA expression or protein expression of BRCA1. Currently, we are preparing an abstract based on these findings for presentation at a national cancer meeting.

For the second part of the aim, we integrate the protein expression data together with mRNA data from an earlier gene expression profiling data on 116 prostate cancer cases in the Physicians' Health Study. The mRNA data were generated using a 6K DASL Illumina array as described previously ${ }^{3}$. We undertook a gene set enrichment analysis to interrogate gene pathways at the mRNA level that are enriched in BRCA1 protein positive vs. negative cancer (Supporting Data, Table III). Using a false discovery rate of $<0.10$, there were eight pathways defined within KEGG that were significantly different in BRCA1 positive prostate cancer including alteration in DNA repair, cell cycle regulation and hedgehog signaling. For future work, we have now expanded the mRNA profiling of prostate cancer cases within the Physicians' Health Study and Health Professionals Follow-up Study and have both protein BRCA1 expression and whole genome mRNA profiling data on 450 patients. The mRNA profiling was completed using whole-transcriptome amplification (WT-Ovation FFPE System V2; NuGEN) followed by hybridization to the GeneChip Human Gene 1.0 ST Array (Affymetrix) which profiles $>28,000$ genes with $~ 26$ probes per gene and initiates amplification at the 3 ' end as well as randomly throughout the transcriptome to improve performance in severely degraded FFPE samples. In our pilot work on this array, we show high reproducibility across technical replicates in our prostate cancer cases even with 11-21 year old blocks ( $r>0.9)$ (Supporting Data, Figure II), and detection of meaningful signatures of high grade vs. low grade cancer (Supporting Data, Figure III). The additional bioinformatics analyses within this larger dataset will provide a more comprehensive picture of the pathways dysregulated in tumors that express BRCA1 protein and that may be driving this aggressive phenotype. Moreover, by incorporating the Connectivity Map algorithms, we may identify potential therapeutic targets that may be useful in BRCA1 positive prostate cancer. Taken together, we have made considerable progress on this aim of the study. 


\section{KEY RESEARCH ACCOMPLISHMENTS}

- Completed immunohistochemical staining for BRCA1 protein in archival radical prostatectomy specimens of 589 men participating in the Health Professionals Follow-Up Study.

- Linked together BRCA1 protein expression data together with mRNA profiling data to identify notable pathways that are differentially expressed in BRCA1 positive and negative prostate cancer.

- Completed pathologic review of cohort on Gleason grading and constructed new tumor tissue microarrays

- Completed biomarker studies on tumor tissue microarrays to assess protein expression of BRCA1 and cellular proliferation

- Created an Access database for standardized collection of clinical database. This resource will be used for future projects

- Created an integrated and cleaned SAS database linking together clinical, tumor biomarker and outcome data for statistical analyses.

- Completed review of tissue specimens for identifying histologically normal tissue and completed DNA extraction with excellent DNA yields

- Corroborated the association between BRCA1 expression and lethal prostate cancer that was previously reported in the Physicians' Healthy Study and drafted a manuscript outlining the results.

- Genotyped common variation 1400 cases from the Health Professionals Followup Study.

- Using the Tagger algorithm implemented in the Haploview program, we completed genotyping for 6 linkage disequilibrium tagging single nucleotide polymorphisms (SNPs) to capture variation with $\mathrm{R}^{2}>0.8$ within $B R C A 1$ and $10 \mathrm{~kb}$ up and downstream.

- Created a dataset to integrate the genotyping data with protein expression of BRCA1 (immunohistochemistry) and the mRNA expression data (extracted from the whole-genome mRNA expression study conducted on the GeneChip Human Gene 1.0 STArray (Affymetrix)).

- Published manuscript on BRCA1 protein expression of lethal prostate cancer in Cancer Research (APPENDIX 1) and presented results at the US Army Prostate Cancer ImPACT meeting in 2011

- Undertook analyses using existing GWAS data and identified SNPs in BRCA1 that are associated with risk of lethal prostate cancer

- Submitted manuscript on the positive association of BRCA1 protein expression with lethal prostate cancer to Molecular Cancer Research on July 2, 2013.

(APPENDIX 2) 
- Presented findings in a podium presentation at the Société International d'Urologie (SIU) Annual Congress in Fukuoka. (APPENDIX 3)

- Presented abstract at the Annual Multi-Institutional SPORE Retreat in Fort Lauderdale, FL. (APPENDIX 4) 


\section{REPORTABLE OUTCOMES}

- Irene Shui, who has been working on the SNPs in BRCA1 analysis, has now been promoted to Research Associate in the Department of Epidemiology at the Harvard School of Public Health.

- Research Fellow working on the project (Kathryn Penney) was promoted to Instructor of Medicine at Harvard Medical School

- This project has helped solidify an international collaboration in prostate cancer patho-epidemiology - the Transdisciplinary Prostate Cancer Partnership (ToPCaP, www.topcapteam.org) bringing together researchers across the disciplines of molecular biology, pathology, epidemiology and biostatistics.

- Dr. Mucci was named the Outstanding Young Investigator from the Prostate Cancer Foundation based on experience supported by this award

- Development of prostate tumor tissue microarrays of the Health Professionals Follow-up Study cohort that is the basis for several new collaborations and research projects

- Presented results at national research meetings

- US Army Prostate Cancer Program ImPACT Meeting, Orlando, FL in 2012

- Multi-Institutional SPORE Retreat Fort Lauderdale, FL March 18 - 20, 2013 (APPENDIX 4)

- Presented results at an international research meeting

- Piotr Zareba presented findings in a podium presentation at the Société International d'Urologie (SIU) Annual Congress in Fukuoka, Japan (presented on October 3, 2012). (APPENDIX 3)

- Submitted manuscript

- Zareba P, Pettersson A, Gerke T, Chowdhury D, Flavin R, Finn S, Penney K, Rider J, Nuttall E, Kantoff P, Stampfer M, Giovannucci E, Loda $M$, Fiorentino M, Mucci L. Protein expression of BRCA1 and lethal prostate cancer progression. (Submitted to Mol Can Res in July 2013). (APPENDIX 2)

- Published manuscript

- Fiorentino M, Judson G, Penney K, Flavin R, Stark J, Fiore C, Fall K, Martin N, Ma J, Sinnott J, Giovannucci E, Stampfer M, Sesso HD, Kantoff PW, Finn S, Loda M, Mucci L. Immunohistochemical expression of BRCA1 and lethal prostate cancer. Cancer Res. 2010; 70: 3136-9. (APPENDIX 1) 


\section{CONCLUSION}

The results from this project and ongoing analyses provide support for our hypothesis that activation of BRCA1 in prostate tumors is a consequence of an increased proliferation rate as a compensatory mechanism of tumor cells to allow DNA repair in highly replicating cells. As a consequence, tumor expression of BRCA1 is a marker of prostate cancer that has a propensity for a lethal phenotype. Beyond cell proliferation, we have identified unique sets of gene pathways altered in BRCA1 positive prostate tumors that may indicate new biomarkers of progression and an understanding of the unique aspects of tumor biology associated with BRCA1. Our analyses on common genetic variation in BRCA1 and prostate cancer-specific mortality provide further compelling evidence for the study hypothesis that BRCA1 plays a key role in the progression of prostate cancer. The integration of data from multiple sources protein expression, mRNA profiling, genetic variation, clinical outcomes - provides a deeper understanding of a unique subset of prostate cancers that may be amenable to specific therapeutic interventions. Finally, we have demonstrated our ability to undertake this large patho-epidemiology cohort and create a biorepository of tumor tissue microarrays from men for the current and future investigations. 


\section{REFERENCES}

References for Introduction:

1. Starita LM, Parvin JD. The multiple nuclear functions of BRCA1: transcription, ubiquitination and DNA repair. Curr Opin Cell Biol. 2003 Jun;15(3):345-50.

2. Chen J, Silver DP, Walpita D, Cantor SB, Gazdar AF, Tomlinson G, et al. Stable interaction between the products of the BRCA1 and BRCA2 tumor suppressor genes in mitotic and meiotic cells. Mol Cell. 1998 Sep;2(3):317-28.

3. Scully R, Chen J, Ochs RL, Keegan K, Hoekstra M, Feunteun J, et al. Dynamic changes of BRCA1 subnuclear location and phosphorylation state are initiated by DNA damage. Cell. 1997 Aug 8;90(3):425-35.

4. Larson JS, Tonkinson JL, Lai MT. A BRCA1 mutant alters G2-M cell cycle control in human mammary epithelial cells. Cancer Res. 1997 Aug 15;57(16):3351-5.

5. MacLachlan TK, Somasundaram K, Sgagias M, Shifman Y, Muschel RJ, Cowan $\mathrm{KH}$, et al. BRCA1 effects on the cell cycle and the DNA damage response are linked to altered gene expression. J Biol Chem. 2000 Jan 28;275(4):2777-85 .

6. Mullan PB, Quinn JE, Harkin DP. The role of BRCA1 in transcriptional regulation and cell cycle control. Oncogene. 2006 Sep 25;25(43):5854-63.

7. Easton DF, Ford D, Bishop DT. Breast and ovarian cancer incidence in BRCA1mutation carriers. Breast Cancer Linkage Consortium. Am J Hum Genet. 1995 Jan;56(1):265-71.

8. Ford D, Easton DF, Bishop DT, Narod SA, Goldgar DE. Risks of cancer in BRCA1-mutation carriers. Breast Cancer Linkage Consortium. Lancet. 1994 Mar 19;343(8899):692-5.

9. Gayther SA, Warren W, Mazoyer S, Russell PA, Harrington PA, Chiano M, et al. Germline mutations of the BRCA1 gene in breast and ovarian cancer families provide evidence for a genotype-phenotype correlation. Nat Genet. 1995 Dec;11(4):428-33.

10. Agalliu I, Gern R, Leanza S, Burk RD. Associations of high-grade prostate cancer with BRCA1 and BRCA2 founder mutations. Clin Cancer Res. 2009 Feb 1;15(3):1112-20.

11. Douglas JA, Levin AM, Zuhlke KA, Ray AM, Johnson GR, Lange EM, et al. Common variation in the BRCA1 gene and prostate cancer risk. Cancer Epidemiol Biomarkers Prev. 2007 Jul;16(7):1510-6.

References for Body:

1. Fiorentino M, Judson G, Penney K, et al. Immunohistochemical expression of BRCA1 and lethal prostate cancer. Cancer research 2010;70:3136-9.

2. Penney KL, Pyne S, Schumacher FR, et al. Genome-wide association study of prostate cancer mortality. Cancer Epidemiol Biomarkers Prev 2010;19:2869-76.

3. Penney KL, Sinnott JA, Fall K, et al. mRNA expression signature of Gleason grade predicts lethal prostate cancer. Journal of clinical oncology : official journal of the American Society of Clinical Oncology 2011;29:2391-6. 


\section{SUPPORTING DATA}

Table 1. Patient and tumor characteristics of the HPFS cohort by BRCA1 protein expression

\begin{tabular}{|c|c|c|c|}
\hline & $\begin{array}{l}\text { BRCA1 Negative } \\
\quad(n=529)\end{array}$ & $\begin{array}{l}\text { BRCA1 Positive } \\
(n=60)\end{array}$ & $p$-value \\
\hline $\begin{array}{l}\text { Age at diagnosis (years), } \\
\quad \text { mean (SD) }\end{array}$ & $65.5(6.3)$ & $66.2(5.6)$ & $0.43^{\mathrm{a}}$ \\
\hline $\begin{array}{l}P S A \text { at diagnosis }(n g / m L), \\
\quad \text { median (IQR) }\end{array}$ & $7.2(5.1-11.4)$ & $8.3(4.7-18.5)$ & $0.17^{b}$ \\
\hline $\begin{array}{l}\text { Follow-up time (years), } \\
\text { median (IQR) }\end{array}$ & $14.3(11.9-17.3)$ & $14.1(9.0-17.5)$ & $0.42^{b}$ \\
\hline \multicolumn{4}{|l|}{ Gleason score, $n(\%)$} \\
\hline $\begin{array}{l}\leq 6 \\
3+4 \\
4+3 \\
\geq 8\end{array}$ & $\begin{array}{c}94(17.8) \\
198(37.4) \\
137(25.9) \\
100(18.9)\end{array}$ & $\begin{array}{l}6(10.0) \\
17(28.3) \\
20(33.3) \\
17(28.3)\end{array}$ & $0.01^{c}$ \\
\hline \multicolumn{4}{|l|}{ Pathologic TNM stage ${ }^{e}, n(\%)$} \\
\hline pT2 & $342(68.7)$ & $35(72.9)$ & $0.34^{c}$ \\
\hline pT3 & $139(27.9)$ & $13(27.1)$ & \\
\hline$p T 4 / N_{+}$ & $17(3.4)$ & $0(0)$ & \\
\hline Lethal prostate cancer, $n(\%)$ & $59(11.2)$ & $15(25.0)$ & $0.002^{d}$ \\
\hline
\end{tabular}


Table 2. Association between BRCA1 protein expression and extent of tumor proliferation, apoptosis, and angiogenesis, Health Professionals Follow-up Study

\begin{tabular}{|c|c|c|c|}
\hline & BRCA1 - & BRCA1 + & $p$-value \\
\hline $\begin{array}{l}\text { Ki67\% positive nuclei, } n(\%) \\
\text { Q1 } 0(0)^{a} \\
\text { Q2 } 0.01-0.11(0.05) \\
\text { Q3 } 0.12-0.45(0.23) \\
\text { Q4 } \geq 0.46(0.95)\end{array}$ & $\begin{array}{l}159(33.5) \\
85(17.9) \\
120(25.3) \\
110(23.2)\end{array}$ & $\begin{array}{l}11(19.3) \\
10(17.5) \\
13(22.8) \\
23(40.4)\end{array}$ & $0.005^{\mathrm{e}}$ \\
\hline $\begin{array}{l}\text { TUNEL \% positive nuclei, } n(\%) \\
\text { Q1 } 0(0) \\
\text { Q2 } 0.1-0.5(0.5) \\
\text { Q3 } 0.6-2.0(2.0) \\
\text { Q4 } \geq 2.1(5.0)\end{array}$ & $\begin{array}{l}124(30.7) \\
136(33.7) \\
64(15.8) \\
80(19.8)\end{array}$ & $\begin{array}{l}10(21.3) \\
15(31.9) \\
5(10.6) \\
17(36.2)\end{array}$ & $0.03^{e}$ \\
\hline 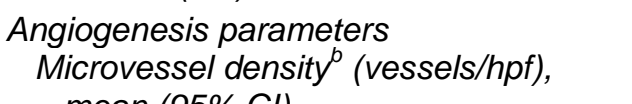 & $69.6(66.7,72.7)$ & $72.5(63.2,83.2)$ & $0.59^{f}$ \\
\hline $\begin{array}{l}\text { mean }(95 \% \mathrm{Cl}) \\
\text { Vessel diameter, }{ }^{c}(\mu \mathrm{m}), \text { mean }(95 \% \mathrm{Cl}) \\
\text { Vessel area, }{ }^{c}\left(\mu \mathrm{m}^{2}\right) \text { mean }(95 \% \mathrm{Cl}) \\
\text { Lumen irregularity, }{ }^{b} \text { mean }(95 \% \mathrm{Cl})\end{array}$ & $\begin{array}{c}24.4(24.0,24.9) \\
477(456,499) \\
3.9(3.8,4.0)^{\mathrm{d}}\end{array}$ & $\begin{array}{c}24.5(23.1,26.1) \\
481(417,555) \\
4.0(3.7,4.3)\end{array}$ & $\begin{array}{l}0.91^{\dagger} \\
0.91^{\dagger} \\
0.64^{\dagger}\end{array}$ \\
\hline $\begin{array}{l}\text { Q1, first quartile; } Q 2 \text {, second quartile; Q3, thir } \\
\text { field; }{ }^{\text {a }} \text { median value within quartile; }{ }^{b} \text { higher is } \\
\text { perfectly circular vessels; }{ }^{p} p \text {-value derived by }\end{array}$ & $\begin{array}{l}\text { e; } Q 4, \text { fourth quartil } \\
\text { ngiogenic; }{ }^{\circ} \text { lower is } \\
\text { are test for trend; }{ }^{\dagger} g\end{array}$ & $\begin{array}{l}\text { confidence interval; } \\
\text { angiogenic; }{ }^{d} \text { score } \\
\text { l linear model }\end{array}$ & $\begin{array}{l}\text { high-powe } \\
\text { indicates }\end{array}$ \\
\hline
\end{tabular}


Table 3. Hazard ratios and $95 \%$ confidence intervals of the association between BRCA1 protein expression lethal prostate cancer, Health Professionals Follow-up Study

\begin{tabular}{|c|c|c|}
\hline & HR (95\% Cl) & $p$-value \\
\hline \multicolumn{3}{|l|}{ Univariate } \\
\hline BRCA1 - & Ref. & 0.003 \\
\hline$B R C A 1+$ & $2.40(1.36-4.23)$ & \\
\hline \multicolumn{3}{|l|}{ Multivariate } \\
\hline BRCA1 - & Ref. & 0.053 \\
\hline$B R C A 1+$ & $1.76(0.99-3.11)$ & \\
\hline Age at diagnosis ${ }^{a}$ & $1.14(0.75-1.71)$ & 0.54 \\
\hline \multicolumn{3}{|l|}{ Gleason score } \\
\hline$\leq 6$ & Ref. & $<0.001^{\mathrm{b}}$ \\
\hline $3+4$ & $2.31(0.51-10.53)$ & \\
\hline $4+3$ & $9.21(2.19-38.8)$ & \\
\hline$\geq 8$ & $17.9(4.28-74.7)$ & \\
\hline $\begin{array}{l}H R \text {, hazard ratio; } \mathrm{Cl} \text {, } \\
\text { by a factor of } 10 ;{ }^{b} \text { tes }\end{array}$ & $\begin{array}{l}\text { lence interval; }{ }^{a} \text { age at } \\
\text { rend }\end{array}$ & \\
\hline
\end{tabular}


Figure I. Co-expression of protein tumor expression of BRCA1 and ki67 in prostate cancer, stratified by Gleason grade

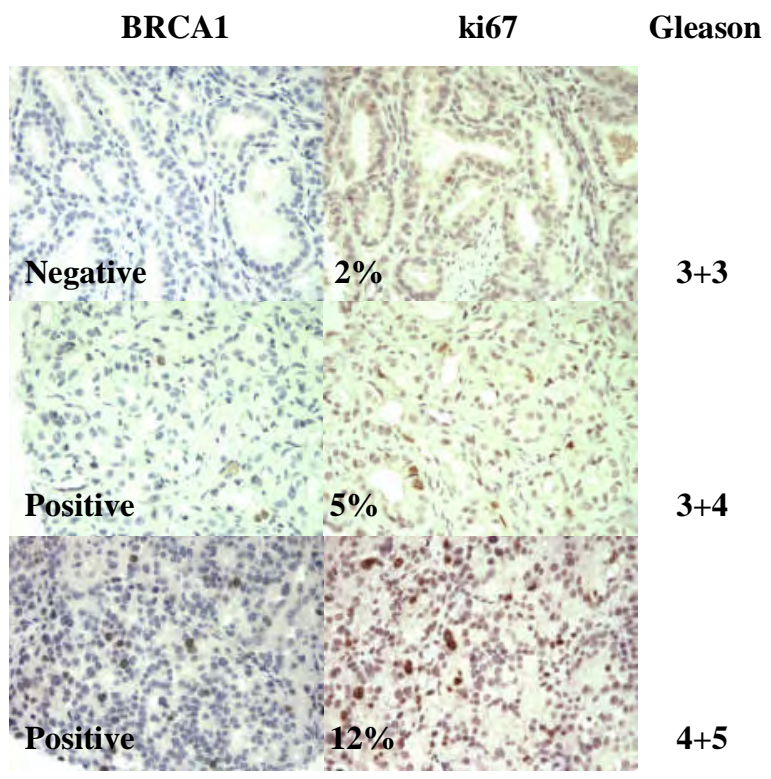


Figure II. Correlation coefficients of mRNA expression of 28,000 genes within technical replicates for an 11-year old tissue block of prostate cancer patient in Physicians' Health Study, Affymetrix 1.0 ST Human Array

Norm. Case: p16; block age: 11

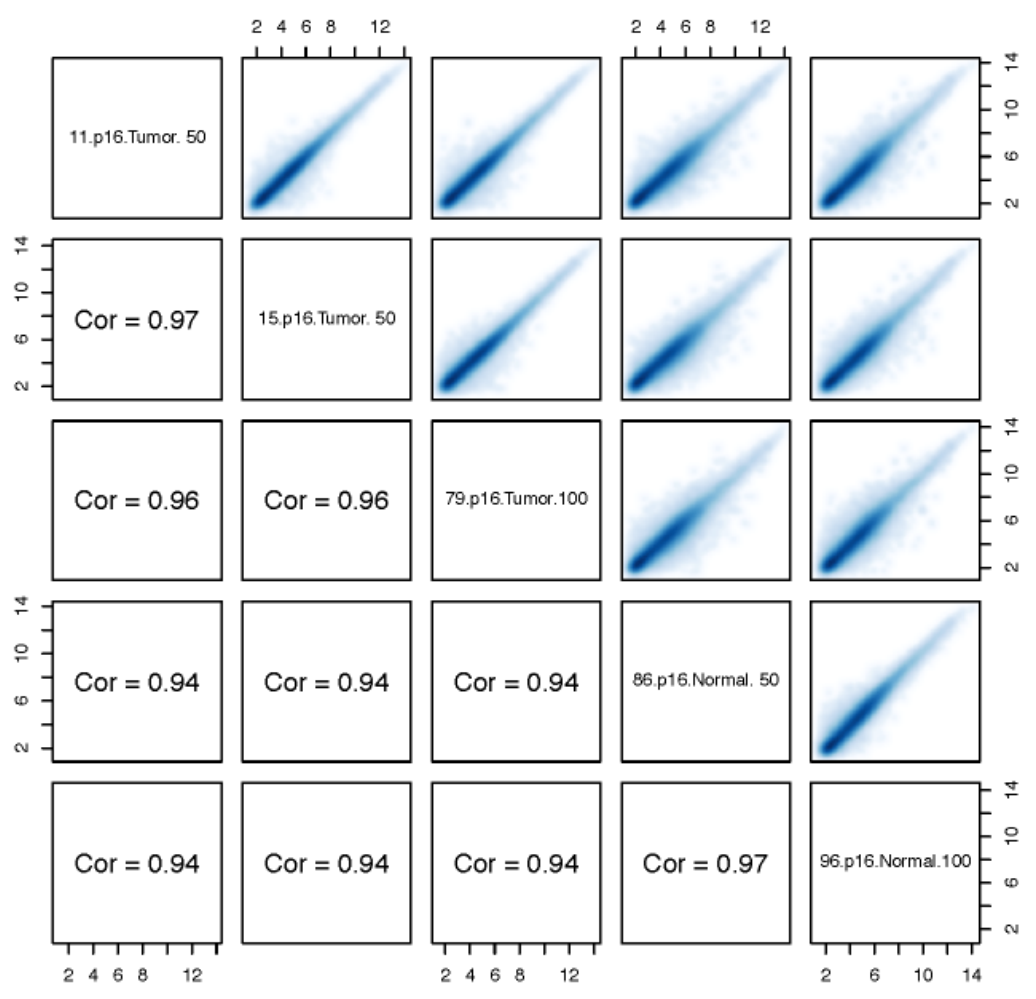


Figure III. Ability of mRNA expression profiling using the Affymetrix 1.0 ST Human array to detect meaningful biological signatures: an example of the 157-gene signature of Gleason grade

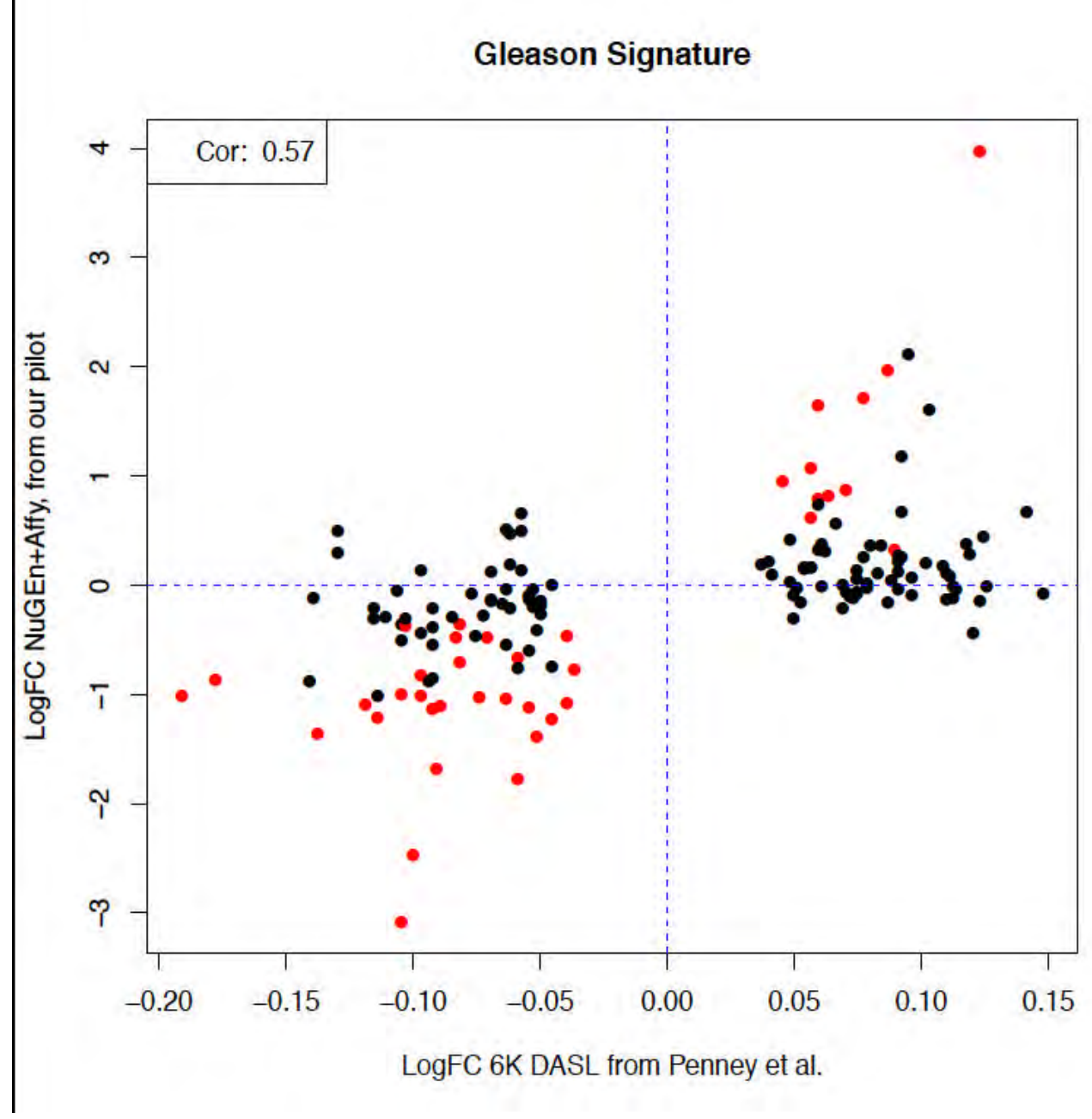


Figure IV. Prostate tumor tissue immunostaining (A) negative and (B) positive for BRCA1. BRCA1 localizes to the nucleus which is stained brown with DAB. Slides were counterstained with hematoxylin and photographed at a magnification of 200x.
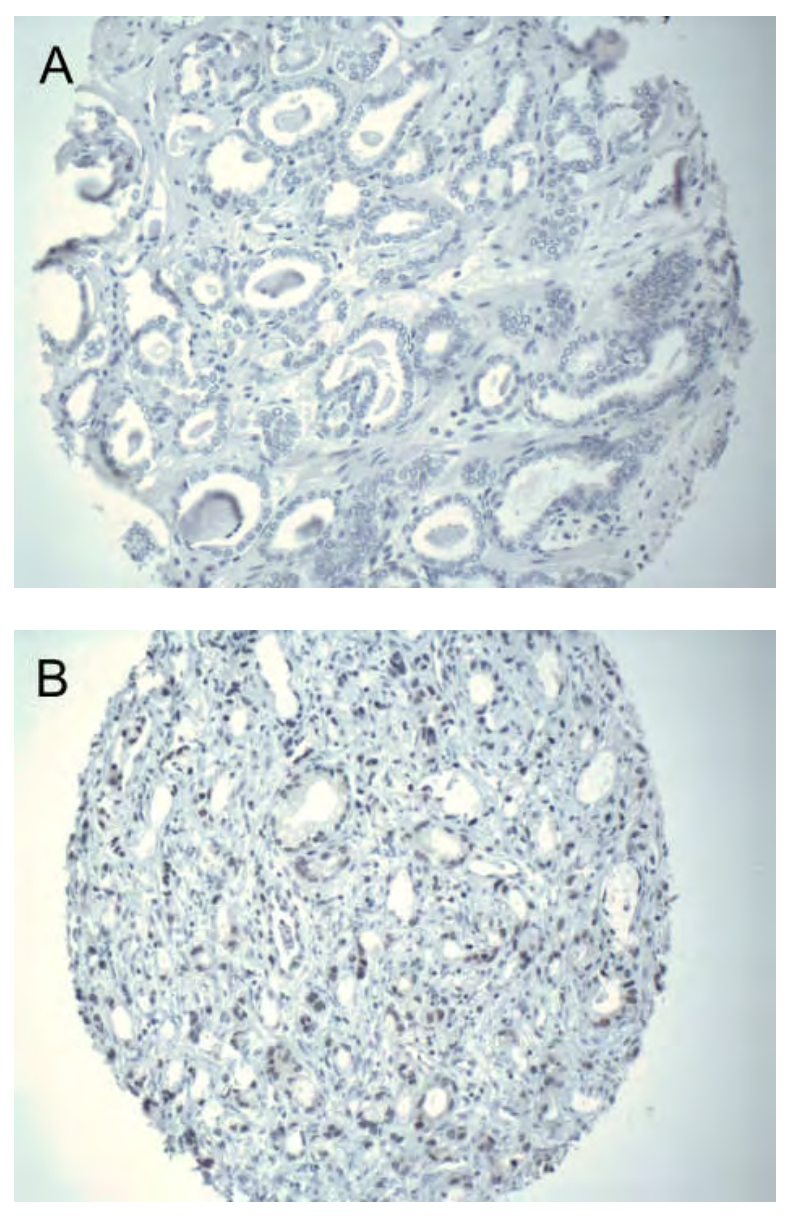


\section{LIST OF APPENDICES}

1. Published manuscript:

- Fiorentino M, Judson G, Penney K, Flavin R, Stark J, Fiore C, Fall K, Martin N, Ma J, Sinnott J, Giovannucci E, Stampfer M, Sesso HD, Kantoff PW, Finn S, Loda M, Mucci L. Immunohistochemical expression of BRCA1 and lethal prostate cancer. Cancer Res. 2010; 70: 3136-9.

2. Submitted manuscript:

- Zareba P, Pettersson A, Gerke T, Chowdhury D, Flavin R, Finn S, Penney K, Rider J, Nuttall E, Kantoff P, Stampfer M, Giovannucci E, Loda M, Fiorentino M, Mucci L. Protein expression of BRCA1 and lethal prostate cancer progression. (Submitted to Mol Can Res in July 2013).

3. Abstract from presentation at the Société International d'Urologie (SIU) Annual Congress in Fukuoka, Japan (presented on October 3, 2012).

- Immunohistochemical expression of BRCA1 and prostate cancer progression in a radical prostatectomy cohort

4. Abstract from presentation at the Multi-Institutional SPORE Retreat Fort Lauderdale, FL (presented on March 18, 2013).

- Molecular markers associated with altered BRCA1 expression in prostate cancer 


\section{Cancer Research}

\section{Immunohistochemical Expression of BRCA1 and Lethal Prostate Cancer}

Michelangelo Fiorentino, Gregory Judson, Kathryn Penney, et al.

Cancer Res 2010;70:3136-3139. Published OnlineFirst April 13, 2010.

Updated version Access the most recent version of this article at: doi:10.1158/0008-5472.CAN-09-4100

Cited Articles This article cites by 21 articles, 11 of which you can access for free at: http://cancerres.aacrjournals.org/content/70/8/3136.full.html\#ref-list-1

Citing articles This article has been cited by 3 HighWire-hosted articles. Access the articles at: http://cancerres.aacrjournals.org/content/70/8/3136.full.html\#related-urls

E-mail alerts Sign up to receive free email-alerts related to this article or journal.

Reprints and To order reprints of this article or to subscribe to the journal, contact the AACR Publications Subscriptions Department at pubs@aacr.org.

Permissions To request permission to re-use all or part of this article, contact the AACR Publications Department at permissions@aacr.org. 


\title{
Immunohistochemical Expression of BRCA1 and Lethal Prostate Cancer
}

\author{
Michelangelo Fiorentino ${ }^{1,9}$, Gregory Judson ${ }^{2,3}$, Kathryn Penney ${ }^{2,3}$, Richard Flavin ${ }^{1}$, Jennifer Stark ${ }^{2,3}$, \\ Christopher Fiore ${ }^{1}$, Katja Fall ${ }^{2,3,10}$, Neil Martin ${ }^{3,6}$, Jing Ma ${ }^{2}$, Jennifer Sinnott ${ }^{2,5}$, \\ Edward Giovannucci ${ }^{2,3,4}$, Meir Stampfer ${ }^{2,3,4}$, Howard D. Sesso ${ }^{3,7}$, Philip W. Kantoff ${ }^{8,11}$, \\ Stephen Finn ${ }^{1}$, Massimo Loda ${ }^{1,11}$, and Lorelei Mucci ${ }^{2,3}$
}

\section{Abstract}

BRCA1 functions as a tumor suppressor; recent work suggests that BRCA1 may also induce cell cycle arrest to allow for DNA repair. We hypothesized that BRCAl expression in prostate tumor tissue may be associated with prostate cancer progression through regulation of the cell cycle. We used immunohistochemistry to evaluate BRCA1 protein expression in archival tumor samples from 393 prostate cancer cases in the Physicians' Health Study. The men were followed prospectively from diagnosis to development of metastases and mortality. Fifteen percent of tumors stained positive for BRCA1. BRCA1-positive tumors had substantially increased tumor proliferation index compared with negative tumors (47.0 Ki67-positive nuclei versus $10.3, P=0.0016)$ and were more likely to develop lethal cancer compared with BRCA1-negative tumors (hazard ratio, 4.6; 95\% confidence interval, 2.4-8.7). These findings strengthen the hypothesis that BRCA1 plays a role in cell cycle control and show that BRCA1 is a marker of clinical prostate cancer prognosis. Cancer Res; 70(8); 3136-9. @2010 AACR.

\section{Introduction}

BRCA1 is a multifunctional tumor suppressor protein implicated in regulating the maintenance of genome integrity through the activation of DNA repair genes, heterochromatin formation, double strand-break repair, homologous recombination events, and ubiquitination (1-3). Recently, a more complex role for BRCA1 was proposed, whereby BRCAl can induce arrest at different cell cycle check points to allow for DNA repair (4-6).

Mutations in BRCA1 have been associated with increased risk of breast, ovarian, and, more recently, prostate cancerparticularly high-grade disease (7-12). However, although mutations in BRCA1 may influence familial prostate cancer risk and progression, few studies have examined BRCAl protein expression in prostate cancer tumor tissue, and, to our knowl-

\begin{abstract}
Authors' Affiliations: ${ }^{1}$ Department of Pathology, Dana-Farber Cancer Institute, Harvard Medical School; ${ }^{2}$ Channing Laboratory, Department of Medicine, Brigham and Women's Hospital, Harvard Medical School; Departments of ${ }^{3}$ Epidemiology, ${ }^{4}$ Nutrition, and ${ }^{5}$ Biostatistics, Harvard School of Public Health; 'Radiation Oncology, Brigham and Women's Hospital; ${ }^{7}$ Division of Preventive Medicine, Department of Medicine, Brigham and Women's Hospital, Harvard Medical School; ${ }^{8}$ Department of Medical Oncology, Dana-Farber Cancer Institute, Harvard Medical School, Boston, Massachusetts; 9Pathology Unit, Addarii Institute, S. Orsola-Malpighi Hospital, Bologna, Italy; 10Uppsala University Hospital, Uppsala, Sweden; and 11The Broad Institute, Cambridge, Massachusetts

Note: M. Loda and L. Mucci share senior authorship.
\end{abstract}

Corresponding Author: Michelangelo Fiorentino, Center for Molecular Oncologic Pathology, Dana-Farber Cancer Institute, 44 Binney Street, JF215H, Boston, MA 02115. Phone: 617-632-4001; Fax: 617-632-4005; E-mail: michelangelo_fiorentino@dfci.harvard.edu.

doi: 10.1158/0008-5472.CAN-09-4100

(C)2010 American Association for Cancer Research. edge, none have correlated expression with cancer progression and mortality. Recently, Schayek and colleagues showed that BRCA1 protein expression in prostate differentially regulates $I G F-I R$ gene expression in an androgen-dependent manner and found significantly elevated BRCA1 levels in prostate cancer in comparison with normal prostate tissue (13). We hypothesized that BRCAl expression could have prognostic relevance in prostate cancer through its regulation of the cell cycle regardless of germ-line mutations.

\section{Materials and Methods}

We undertook a prospective study among 392 men in the Physicians' Health Study (refs. 14, 15; http://clinicaltrials.gov identifier: NCT00000500) who were diagnosed with prostate cancer from 1983 to 2004 . We constructed tumor tissue microarrays from archival prostatectomy and trans urethral resection of the prostate tumor tissue specimens using three 0.6-mm cores of tumor per case. Immunohistochemical staining was performed on $5-\mu \mathrm{m}$ sections of the tissue microarrays (TMA) to assess BRCA1 expression [monoclonal MS110 antibody specific for the $\mathrm{NH}_{2}$ terminus of the $220 \mathrm{kDa} B R C A 1$ protein (Calbiochem), diluted 1:50 after EDTA-based antigen retrieval] and cell proliferation [polyclonal anti Ki67 antibody (Vector Labs), diluted 1:2,000 after citrate-based antigen retrieval]. MCF7 and HCC1937 cell lines were used as positive and negative controls for BRCAl immunostaining, respectively. Because of the small proportion of stained nuclei and the homogeneous intensity of the immunostaining, the study pathologists (M.F. and R.F.) scored tumor expression of BRCA1 manually as positive or negative; Ki67 proliferation index was scored by quantitative image analysis (Ariol SL-50, 
Figure 1. Comparative representation of BRCA1 expression and Ki67 proliferative index in serial sections of prostate cancer tissues with different Gleason scores. The brown immunostaining is nuclear for both BRCA1 and Ki67; slides are counterstained with hematoxylin (magnification $\times 200$ ).

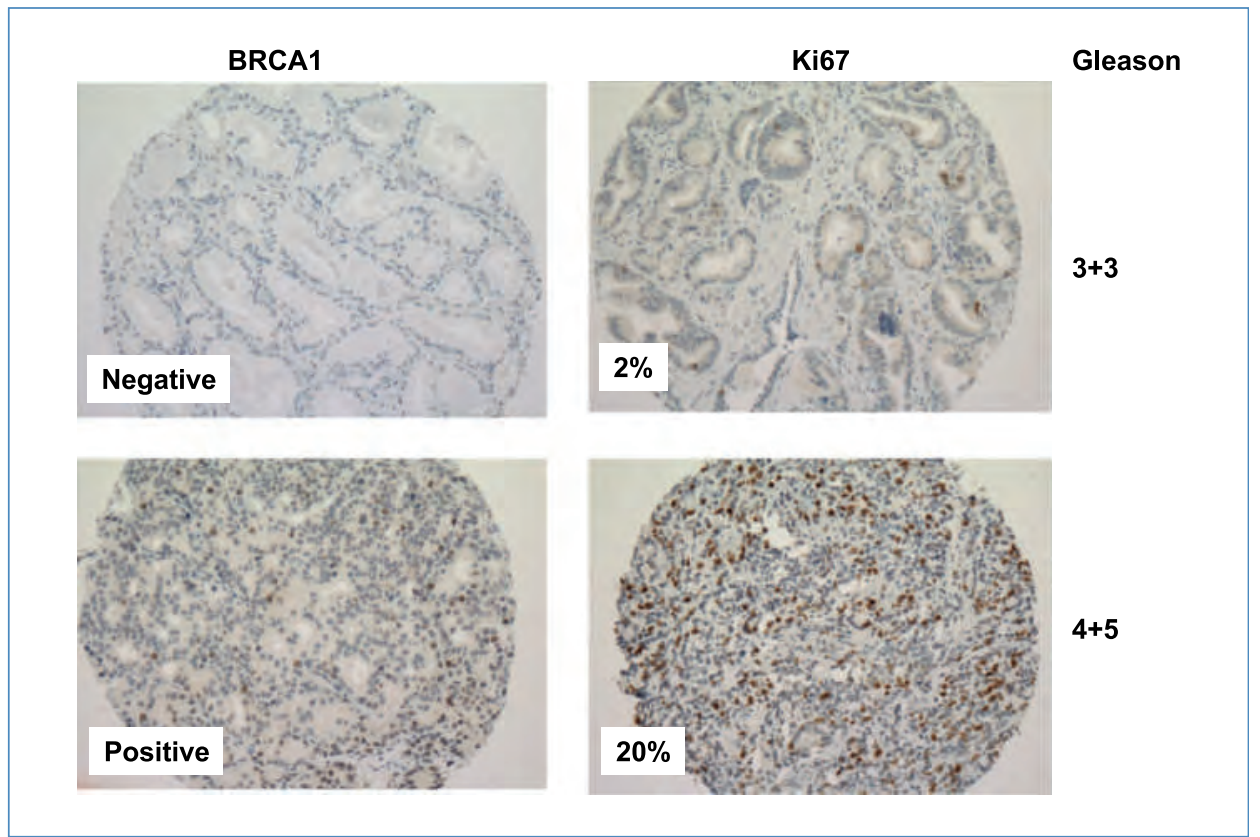

Applied Imaging; Fig. 1). The possible heterogeneity of the immunohistochemical staining for BRCAl was also controlled using whole sections of 14 prostate cancer cases included in the TMAs. RNA expression levels of BRCA1 were available from a subset of participants $(n=116)$ using a gene expression profiling study that applied the DASL Illumina 6K array (16). The study was approved by Partners Health Care Institutional Review Board.

We abstracted data on age, stage, and prostate specific antigen (PSA) levels at diagnosis from medical records, and conducted a standardized histopathologic review for Gleason score $(17,18)$. The men were followed prospectively since diagnosis for the development of bony metastases and mortality through March 2009, without loss to follow-up.

We evaluated whether BRCA1-positive and BRCA1negative tumor status based on immunohistochemistry differed according to Gleason score, tumor stage, PSA level, and age at diagnosis using generalized linear regression for continuous data and $\chi^{2}$ tests for categorical data. In addition, we assessed BRCA1-positive and BRCA1-negative prostate tumors for the number of Ki67-positive nuclei as well as BRCA1 RNA expression levels using ANOVA. Mean Ki67-positive

\begin{tabular}{|c|c|c|c|}
\hline & BRCA1 negative & BRCA1 positive & $\boldsymbol{P}$ \\
\hline$n$ & 332 & 60 & \\
\hline Age at diagnosis $(95 \% \mathrm{Cl})$ & $66.5(65.7-67.2)$ & $67.3(65.6-69.0)$ & 0.37 \\
\hline PSA at diagnosis $(95 \% \mathrm{Cl})$ & $10.2(6.0-14.4)$ & $27.0(15.9-38.1)$ & 0.0056 \\
\hline Mean follow-up time & $11.0(10.5-11.4)$ & $8.8(7.7-9.9)$ & 0.0006 \\
\hline$n$ dead $/$ metastases ( $\%$ of total) & $24(7.2)$ & $16(26.7)$ & $<0.0001$ \\
\hline Gleason score, $n(\%)$ & & & $0.004^{\star}$ \\
\hline $4-6$ & 97 (29.2) & $10(16.7)$ & \\
\hline $3+4$ & $116(34.9)$ & $19(31.7)$ & \\
\hline $4+3$ & $65(19.6)$ & $10(16.7)$ & \\
\hline 8-10 & $52(15.7)$ & $21(35.0)$ & \\
\hline Stage, $n(\%)$ & & & $0.0005^{*}$ \\
\hline $\mathrm{pT}_{2}$ & 207 (62.3) & $26(43.3)$ & \\
\hline $\mathrm{pT}_{3}$ & $72(21.7)$ & $4(6.7)$ & \\
\hline $\mathrm{pT}_{4} / \mathrm{N}_{1}$ & $4(1.2)$ & $4(6.7)$ & \\
\hline
\end{tabular}


nuclei scores were $\log _{10}$ transformed before analysis to account for the uneven distribution of scores in the raw data. To assess the extent to which BRCAl status was associated with poor progression, we used Cox proportional hazards models and examined the association between BRCAl status and lethal prostate cancer, defined as development of distant metastases or prostate cancer-specific mortality. All statistical tests were two-sided.

This project was approved by the Partners Health Care Institutional Review Board.

\section{Results}

Normal prostate tissue did not stain for BRCA1; however, $15.3 \%(n=60)$ of prostate tumor samples showed patchy nuclear positive immunostaining with a punctuate pattern (Fig. 1). There was a total correspondence between BRCAl staining in the TMA cores and in the whole sections obtained from the selected 14 corresponding donor blocks in terms of signal intensity and percentage of positive nuclei. Cases that stained positively for BRCA1 had substantially and significantly higher Gleason score, higher PSA levels at diagnosis, and more advanced stage compared to those with tumors that did not stain for BRCA1 (Table 1). Moreover, BRCA1-positive tumors were marked by substantially increased tumor proliferation index compared with BRCA1-negative tumors (47.0 Ki67positive nuclei versus $10.3, P=0.0016)$. Tumors staining positive for BRCAl also showed increased BRCA1 mRNA relative expression [mean, 10.5; 95\% confidence interval $(95 \%$ CI), 10.2-10.8] compared with tumors negative for BRCA1 (mean, 9.9; 95\% CI, 9.7-10.1, $P$ for difference $=0.008$ ).

During a mean follow-up of 10.6 years, 40 men died of cancer or developed bony metastases. Sixteen of the 60 men (26.7\%) with BRCAl-positive tumors died of prostate cancer, compared with 24 of $332(7.2 \%)$ men who were BRCA1 negative [hazard ratio (HR), 4.6; 95\% CI, 2.4-8.7]. This association remained statistically significant after adjusting for age at diagnosis and Gleason score (HR, 2.5; 95\% CI, 1.3-4.8). Interestingly, although BRCA1-positive tumors had substantially increased tumor proliferative index, the association of BRCA1 and lethal prostate cancer remained significant after controlling for $\log _{10}$-transformed Ki67 expression (HR, 3.6; 95\% CI, 1.6-8.0).

\section{Discussion}

This study represents the first demonstration of a direct correlation between the expression of BRCA1 and the Ki67 proliferative index in prostate cancer and further strengthens the hypothesis that BRCA1 may play a role in cell cycle control and is a potent independent marker of clinical prognosis. Ki67 is a well-known predictor of adverse prognosis and resistance to therapy in prostate cancer $(19,20)$. In addition, association of increased proliferation and BRCA1 protein immunohistochemical expression was recently described in breast cancer epithelial cells from BRCAl mutation carriers possibly as a result of epidermal growth factor receptor pathway activation (21). In agreement with the recent observation by Schayek and colleagues (13), we found that BRCA1 was not expressed in normal prostate tissue. We hypothesize that this localization of BRCA1 only to the most aggressive tumors may reflect an inefficient attempt to upregulate DNA repair mechanisms in prostate epithelial cells with high proliferative rate and extensive genetic instability.

Cases whose prostate tumors stained positive for BRCA1 had significantly higher Gleason score, PSA at diagnosis, and tumor proliferation as well as significantly worse prognosis than those with negative BRCAl staining. In addition, mRNA levels were also increased in the BRCA1 proteinpositive tumors, indicating a transcriptional-level control in these cases. Taken together, these observations support the hypothesis that the BRCAl gene may hold another biological function apart from its tumor suppressor activity.

Although the mechanism of cell cycle regulation by BRCA1 still requires further exploration, we can conclude that the immunohistochemical investigation of BRCA1 protein expression represents a new tool for understanding the cell cycle regulation in the development of prostate cancer to lethal disease.

\section{Disclosure of Potential Conflicts of Interest}

No potential conflicts of interest were disclosed.

\section{Acknowledgments}

We thank the participants in the Physicians' Health Study for their longstanding participation, and Julia Fleet, Joanne Smith, Vadim Bubes, and Haiyan Zhang for their assistance with data collection and programming.

\section{Grant Support}

Department of Defense (W81XWH-05-1-0562) and the Dana-Farber/Harvard Cancer Center Prostate Specialized Programs of Research Excellence. The Physicians' Health Study is supported by grants CA34944, CA40360, and CA097193 from the National Cancer Institute, and grants HL-26490 and HL-34595 from the National Heart, Lung, and Blood Institute. L. Mucci is a Michael Milken Scholar of the Prostate Cancer Foundation.

The costs of publication of this article were defrayed in part by the payment of page charges. This article must therefore be hereby marked advertisement in accordance with 18 U.S.C. Section 1734 solely to indicate this fact.

Received 11/09/2009; revised 12/15/2009; accepted 01/06/2010; published OnlineFirst 04/06/2010.

\section{References}

1. Chen J, Silver DP, Walpita D, et al. Stable interaction between the products of the BRCA1 and BRCA2 tumor suppressor genes in mitotic and meiotic cells. Mol Cell 1998;2:317-28.

2. Scully $R$, Chen $J$, Ochs $R L$, et al. Dynamic changes of BRCA1 subnuclear location and phosphorylation state are initiated by DNA damage. Cell 1997;90:425-35.

3. Starita LM, Parvin JD. The multiple nuclear functions of BRCA1: transcription, ubiquitination and DNA repair. Curr Opin Cell Biol 2003;15:345-50.

4. Larson JS, Tonkinson JL, Lai MT. A BRCA1 mutant alters $\mathrm{G}_{2}-\mathrm{M}$ cell cycle control in human mammary epithelial cells. Cancer Res 1997;57:3351-5.

5. MacLachlan TK, Somasundaram K, Sgagias M, et al. BRCA1 effects 
on the cell cycle and the DNA damage response are linked to altered gene expression. J Biol Chem 2000;275:2777-85.

6. Mullan PB, Quinn JE, Harkin DP. The role of BRCA1 in transcriptional regulation and cell cycle control. Oncogene 2006;25:5854-63.

7. Agalliu I, Gern R, Leanza S, Burk RD. Associations of high-grade prostate cancer with BRCA1 and BRCA2 founder mutations. Clin Cancer Res 2009;15:1112-20.

8. Douglas JA, Levin AM, Zuhlke KA, et al. Common variation in the BRCA1 gene and prostate cancer risk. Cancer Epidemiol Biomarkers Prev 2007;16:1510-6.

9. Mitra A, Fisher C, Foster CS, et al. Prostate cancer in male BRCA1 and BRCA2 mutation carriers has a more aggressive phenotype. $\mathrm{Br} \mathrm{J}$ Cancer 2008;98:502-7.

10. Ramus SJ, Gayther SA. The contribution of BRCA1 and BRCA2 to ovarian cancer. Mol Oncol 2009;3:138-50.

11. Risch HA, McLaughlin JR, Cole DE, et al. Population BRCA1 and BRCA2 mutation frequencies and cancer penetrances: a kin-cohort study in Ontario, Canada. J Natl Cancer Inst 2006;98:1694-706.

12. Tryggvadottir $L$, Vidarsdottir $L$, Thorgeirsson $T$, et al. Prostate cancer progression and survival in BRCA2 mutation carriers. J Natl Cancer Inst 2007;99:929-35.

13. Schayek H, Haugk K, Sun S, True LD, Plymate SR, Werner H. Tumor suppressor BRCA1 is expressed in prostate cancer and controls insulin-like growth factor I receptor (IGF-IR) gene transcription in an androgen receptor-dependent manner. Clin Cancer Res 2009;15: 1558-65.
14. Gaziano JM, Glynn RJ, Christen WG, et al. Vitamins E and C in the prevention of prostate and total cancer in men: the Physicians' Health Study II randomized controlled trial. JAMA 2009; 301:52-62.

15. Hennekens $\mathrm{CH}$, Eberlein $\mathrm{K}$. A randomized trial of aspirin and $\beta$-carotene among U.S. physicians. Prev Med 1985;14:165-8.

16. Setlur SR, Mertz KD, Hoshida Y, et al. Estrogen-dependent signaling in a molecularly distinct subclass of aggressive prostate cancer. J Natl Cancer Inst 2008;100:815-25.

17. Stark JR, Perner S, Stampfer MJ, et al. Gleason score and lethal prostate cancer: does $3+4=4+3$ ? J Clin Oncol 2009;27:3459-64.

18. Müntener M, Epstein JI, Hernandez DJ, et al. Prognostic significance of Gleason score discrepancies between needle biopsy and radical prostatectomy. Eur Urol 2008;53:767-75.

19. Zellweger T, Günther $S$, Zlobec I, et al. Tumour growth fraction measured by immunohistochemical staining of Ki67 is an independent prognostic factor in preoperative prostate biopsies with small-volume or low-grade prostate cancer. Int J Cancer 2009;124:2116-23.

20. Pollack A, DeSilvio M, Khor LY, et al. Ki-67 staining is a strong predictor of distant metastasis and mortality for men with prostate cancer treated with radiotherapy plus androgen deprivation: Radiation Therapy Oncology Group Trial 92-02. J Clin Oncol 2004;22: 2133-40.

21. Burga LN, Tung NM, Troyan SL, et al. Altered proliferation and differentiation properties of primary mammary epithelial cells from BRCA1 mutation carriers. Cancer Res 2009;69:1273-8. 
Running title: BRCA1 protein expression in prostate cancer

\section{Title}

Protein Expression of BRCA1 and Lethal Prostate Cancer Progression

\section{Authors}

Piotr Zareba, ${ }^{1}$ Andreas Pettersson, ${ }^{2}$ Travis Gerke,${ }^{2}$ Dipanjan Chowdhury, ${ }^{3}$ Richard Flavin, ${ }^{4,5}$

Stephen Finn, ${ }^{4}$ Kathryn Penney, ${ }^{2,6}$ Jennifer R. Rider, ${ }^{2,6}$ Elizabeth J. Nuttall, ${ }^{2}$ Philip W.

Kantoff, ${ }^{7.8}$ Meir J. Stampfer, ${ }^{2,6,9}$ Edward Giovannucci, ${ }^{2,6,9}$ Massimo Loda, ${ }^{6,8}$ Michelangelo

Fiorentino, ${ }^{\dagger 2,10}$ Lorelei A. Mucci ${ }^{\dagger 2,6}$ on behalf of the Transdisciplinary Prostate Cancer

Partnership (ToPCaP, topcapteam.org)

${ }^{1}$ Division of Urology, McMaster University, Hamilton, ON, Canada

${ }^{2}$ Department of Epidemiology, Harvard School of Public Health, Boston, MA, United States

${ }^{3}$ Department of Radiation Oncology, Dana-Farber Cancer Institute, Harvard Medical School,

Boston, MA, United States

${ }^{4}$ Department of Pathology, Dana-Farber Cancer Institute, Harvard Medical School, Boston, MA,

United States

${ }^{5}$ Department of Pathology, St. James's Hospital, Dublin, Ireland

${ }^{6}$ Channing Division of Network Medicine, Department of Medicine, Brigham and Women's Hospital, Harvard Medical School, Boston, MA, United States

${ }^{7}$ Department of Medical Oncology, Dana-Farber Cancer Institute, Harvard Medical School, Boston, MA, United States

${ }^{8}$ The Broad Institute of MIT and Harvard, Cambridge, MA, United States

${ }^{9}$ Department of Nutrition, Harvard School of Public Health, Boston, MA, United States

${ }^{10}$ Pathology Unit, Addarii Institute, S. Orsola-Malpighi Hospital, Bologna, Italy

${ }^{\dagger}$ These authors share senior authorship 
Corresponding author: Dr. Lorelei A. Mucci, Department of Epidemiology, Harvard School of Public Health, $9^{\text {th }}$ floor, 677 Huntington Ave, Boston, MA, 02115, United States; +1 (617) 4321732; fax +1 (617) 566-7805; lmucci@ @sph.harvard.edu

Keywords: BRCA1, DNA damage and repair mechanisms, prostate cancer, tumor progression, tumor biomarker

Support: This work was supported by the US Army Prostate Cancer Program (W81XWH-10-10552 to L.A.M.); the Dana-Farber/Harvard Cancer Center SPORE in Prostate Cancer (P50CA090381 to P.W.K.); and the National Cancer Institute (CA136578 to L.A.M., R01CA141298 to M.J.S.). The Health Professionals Follow-up Study is supported by the National Cancer Institute (P01CA055075 to W. Willett). L.A.M., K.L.P., J.R.R. and S.F. are supported by the Prostate Cancer Foundation. A.P. was supported by the Swedish Research Council (reg. no. 2009-7309) and the Birgit and Hellmuth Hertz Foundation.

Conflict of Interest: The authors declare no conflicts of interest.

Word Count: 2,688 Tables and Figures: 4 
Running title: BRCA1 protein expression in prostate cancer

\section{$1 \quad$ ABSTRACT}

2 BRCA1 is a tumor suppressor protein involved in DNA repair and is often overexpressed in

3 prostate cancer tumors. Although $B R C A 1$ mutations are known to promote carcinogenesis, the

4 role of BRCA1 protein expression in prostate cancer progression is poorly understood. To

5 approach this question, we performed immunohistochemical staining for BRCA1 protein in

6 archival tumor tissue from radical prostatectomy specimens of 589 men participating in the

7 Health Professionals Follow-Up Study, characterizing staining as present or absent. Tumor

8 proliferation was assessed by immunostaining for Ki67 and apoptosis was assessed using a

9 TUNEL assay. Subjects were followed prospectively through 2011 from the date of diagnosis

10 until the development of metastases or death. Immunohistochemical staining was positive for

11 BRCA1 protein in 60 patients (10\%). BRCA1-positive tumors were of higher grade than

12 BRCA1-negative tumors $\left(p_{\text {trend }}=0.01\right)$ and exhibited higher proliferative and apoptotic indices

13 ( $p_{\text {trend }}=0.005$ and 0.03 , respectively). During a median follow-up time of 14 years, 59 men

$14(11 \%)$ in the BRCA1-negative group and 15 men $(25 \%)$ in the BRCA1-positive group developed

15 metastases or died of prostate cancer. On unadjusted analysis, there was a strong positive association between BRCA1 protein expression and risk of lethal prostate cancer (HR 2.40, 95\%

17 CI 1.36-4.23, $p=0.003$ ). After adjusting for age at diagnosis and Gleason score, there remained

18 a higher risk of lethal prostate cancer among men with BRCA1-positive tumors (HR 1.76, 95\%

19 CI $0.99-3.11, p=0.053)$. Our findings suggest that BRCA1 expression is a marker of an

20 aggressive prostate cancer phenotype and may be an independent predictor of cancer

21 progression. 
Running title: BRCA1 protein expression in prostate cancer

\section{INTRODUCTION}

$B R C A 1$ encodes a tumor suppressor protein that plays an integral role in maintaining genomic integrity. The BRCA1 protein is a component of the homologous recombination pathway that repairs DNA double strand breaks (1), and may also facilitate DNA repair by regulating chromatin remodeling, cell cycle checkpoint control, and mitotic spindle pole assembly (2-5). Failure to repair damaged DNA can produce mutations that promote carcinogenesis (5-7), and germline mutations in BRCA1 that result in an absent or defective BRCA1 protein have been linked to an increased risk of developing cancers of the breast, the ovary, and more recently the prostate $(8,9)$.

Although deficiency of functional BRCA1 protein promotes carcinogenesis, the role of BRCA1 in cancer progression is poorly understood. Paradoxically, immunohistochemical expression of BRCA1 is higher in prostate tumor tissue than in benign prostatic epithelium $(10,11)$. Increased expression of BRCA1 has also been shown to be associated with decreased survival in patients with ovarian $(12,13)$, breast (14), and non-small cell lung carcinomas (15), indicating the possibility that BRCA1 may promote tumor growth and survival. BRCA1 may also be involved in prostate cancer survival, as our group recently reported a positive association between BRCA1 protein expression and higher Gleason grade, tumor proliferative index, and prostate cancer mortality in a large cohort of male physicians (11). The objective of the current study is to corroborate the association between BRCA1 protein expression and prostate cancer survival in a prospective cohort of men treated predominantly with radical prostatectomy.

\section{MATERIALS AND METHODS}

\section{Study Population}


This project was nested among men with prostate cancer who are participants in the prospective Health Professionals' Follow-Up Study. In 1986, it enrolled 51,529 male dentists, pharmacists, optometrists, osteopaths, podiatrists, and veterinarians between 40 and 75 years of age. Participants are asked to complete a questionnaire relating to their medical history and lifestyle habits every two years.

Between 1986 and 2004, 5,626 study participants were diagnosed with prostate cancer. Incident cases of prostate cancer were ascertained either by self-report or by review of death certificates. Of these, archival surgical specimens were obtained for 1,023 men. Immunohistochemical staining for BRCA1 was performed in specimens from 589 men, and they comprise the cohort used for the current analysis. All study participants provided informed consent and approval for the study was obtained from the Institutional Review Board of the Harvard School of Public Health and Partners Health Care.

\section{Data Collection}

Data on age, pathological stage, and prostate-specific antigen (PSA) level at diagnosis were abstracted from medical records and pathology reports. H\&E slides from archival prostatectomy specimens were re-reviewed for Gleason grade and other histologic features by study pathologists (M.F., R.F., S.F., M.L.).

Dates and causes of death were assigned by way of a centralized review of medical records and death certificates by study physicians. Since 2000 , data on development of distant metastases were also tracked by way of patient questionnaires and review of medical records.

\section{Immunohistochemical Analysis}


Within the Health Professionals Follow-up Study, we have retrieved the archival formalin-fixed, paraffin-embedded tumor tissue specimens. The majority of tissue came from prostatectomy specimens (93\%), with the remainder from transurethral resection of prostate (TURP) tissue (6\%) and lymph nodes (one specimen). All cases were reviewed by pathologists to identify areas of high-density tumor for construction of tissue microarrays. Using a manual arrayer, we sampled at least three tumor cores $(0.6 \mathrm{~mm})$ from each case and embedded them in the recipient tissue microarray block; five tissue microarrays containing the 589 cases were used in this study. Immunohistochemical staining was performed on $5 \mu \mathrm{m}$ sections of each tissue microarray as previously described (11). Briefly, staining for BRCA1 was performed using a monoclonal MS110 antibody specific for the N-terminal of the functional BRCA1 protein (Calbiochem), diluted 1:50 after EDTA-based antigen retrieval (see Figure 1). BRCA1 tumor expression was graded manually by the study pathologists as either BRCA1 present or absent, regardless of staining intensity. Data was also available on Ki67 proliferative rate for 531 patients using a polyclonal antibody (Vector Labs), diluted 1:2,000 after citrate-based antigen retrieval, and scored by quantitative image analysis as the number of positive nuclei over the total number of neoplastic nuclei. The TUNEL assay was used to assess apoptosis and the apoptotic rate was scored semi-quantitatively by eye in 451 patients. Presence of TMPRSS2:ERG rearrangements was determined in 574 patients by immunohistochemical staining for ERG protein (16). A subset of 433 specimens was also analyzed for morphologic markers of tumor angiogenesis (vessel density, area, diameter, and irregularity) using semiautomated image analysis as described in a previous report (17).

\section{Statistical Analysis}


We compared age at diagnosis, PSA level at diagnosis, and tumor grade and stage according to BRCA1 expression status. Proliferative and apoptotic indices, ERG protein expression, and markers of angiogenesis were also assessed for correlation with BRCA1 expression. Associations were tested using chi-square tests for trend for categorical variables and general linear models or the Wilcoxon rank sum test for continuous variables. Ki67 and TUNEL scores were categorized into quartiles for the purpose of the analysis to account for their non-normal distribution, while the angiogenesis parameters were log-transformed.

The relationship between BRCA1 expression and prostate cancer progression was assessed using Cox proportional hazards models to calculate hazard ratios (and 95\% confidence intervals). The event of interest was defined as the development of bone or visceral metastases or death due to prostate cancer. Person-time was calculated from the date of diagnosis to development of metastases, death due to prostate cancer-related causes (whichever occurred earlier), or censored at death from other causes or the end of follow-up (January 2012). In multivariate models, estimates were adjusted for age at diagnosis (continuous, in years), Gleason grade $(\leq 6,3+4$, $4+3$, and $\geq 8$ ), and Ki67 proliferative index (categorized into quartiles). Interaction terms were used to assess for effect modification by specimen type (RP or TURP), Gleason grade, and Ki67 proliferative index. All analyses were performed using Statistical Analysis Software (SAS) version 9.1 (Cary, NC).

\section{RESULTS}

A total of 589 men with prostate cancer who were participants in the Health Professionals Follow-up Study were included in the analysis. Mean age at diagnosis was 65.5 years and median PSA at diagnosis was $7.2 \mathrm{ng} / \mathrm{mL}$ (interquartile range $5.1-11.7 \mathrm{ng} / \mathrm{mL}$ ). The men had 
cancers that were primarily low or intermediate grade, with $17 \%$ being assigned a Gleason grade of 6 or less and $37 \%$ being assigned a Gleason grade of $3+4$. Among men who underwent radical prostatectomy, extraprostatic extension (pT3) was found in 152 specimens (28\%), while $3 \%$ of men had locally advanced or lymph node-positive disease (pT4/N+).

Ten percent $(\mathrm{N}=60)$ of the patients had tumors that stained positive for BRCA1. Patient and tumor characteristics by BRCA1 expression status are shown in Table 1. Patients with BRCA1positive tumors did not differ from those with BRCA1-negative tumors in age (mean age 66.2 years vs. 65.5 years, respectively, $p=0.43$ ) or PSA level at diagnosis (median PSA $8.3 \mathrm{ng} / \mathrm{mL}$ vs. $7.2 \mathrm{ng} / \mathrm{mL}, p=0.17)$. There was, however, a strong association between BRCA1 expression status and Gleason grade, with BRCA1-positive tumors being of higher grade $\left(p_{\text {trend }}=0.01\right)$ than BRCA1-negative tumors. Among men treated with radical prostatectomy, no correlation between BRCA1 expression and pathologic TNM stage was found.

Compared to BRCA1-negative tumors, tumors expressing BRCA1 exhibited a higher degree of cell proliferation, as measured by Ki67 expression $\left(p_{\text {trend }}=0.005\right)$, and a higher degree of apoptosis, as measured by the TUNEL assay $\left(p_{\text {trend }}=0.03\right.$; see Table 2$)$. These associations persisted after adjustment for Gleason grade (analyses not shown). No association was found between BRCA1 status and presence of TMPRSS2:ERG expression or markers of angiogenesis.

During a median follow-up of 14 years after diagnosis, 74 men developed distant metastases or died of prostate cancer-related causes, $59(11 \%)$ in the BRCA1-negative group and $15(25 \%)$ in the BRCA1-positive group (see Table 1). On unadjusted analysis, there was a strong positive association between BRCA1 protein expression and risk of lethal prostate cancer (HR 2.40, 95\% CI 1.36-4.23, $p=0.003$; see Table 3). Adjustment for Gleason grade alone attenuated this association (HR 1.75, 95\% CI 0.99-3.09, $p=0.056$ ), but adjustment for age at diagnosis alone 
did not (HR 2.39, 95\% CI 1.36-4.22, $p=0.003)$. After adjustment for both age at diagnosis and Gleason score, there remained a higher risk of lethal prostate cancer in men with BRCA1positive tumors (HR 1.76, 95\% CI 0.99-3.11, $p=0.053$ ). Additional adjustment for Ki67 proliferative index or TUNEL apoptotic index did not attenuate the association between BRCA1 expression and survival (data not shown). We found no statistically significant difference in the relationship between BRCA1 expression and lethal prostate cancer by specimen type (RP or TURP), Gleason grade, or proliferative index (data not shown).

\section{DISCUSSION}

In this large cohort of men with prostate cancer, tumors expressing BRCA1 protein demonstrated a more aggressive phenotype than BRCA1-negative tumors, with higher Gleason scores as well as increased indices of proliferation and apoptosis. BRCA1 protein expression was also associated with a 2-fold increase in risk of progression to lethal prostate cancer after adjustment for age and Gleason score.

BRCA1 protein has previously been shown to be overexpressed in malignant prostate glands compared to normal prostatic epithelium $(10,11)$. Although we did not quantify expression of BRCA1 protein in benign prostate tissue, we did confirm the positive association between tumor BRCA1 expression and both Gleason grade and proliferative index that was previously found in the Physicians' Health Study (PHS) (11). In addition, the current study is the first to report a positive association between BRCA1 expression and apoptotic index, and also the first to show that the associations between BRCA1 expression and both tumor proliferation and apoptosis are independent of Gleason grade. In keeping with the PHS analysis, which showed BRCA1 expression to be a strong predictor of lethal prostate cancer even after adjustment for age and Gleason grade (HR 2.5, 95\% CI 1.3-4.8), multivariate analysis of the HPFS cohort revealed a 
$76 \%$ (HR 1.76, 95\% CI 0.99-3.11, $p=0.053$ ) higher risk of developing metastases or prostate cancer-related death. Taken together, the results from these two cohorts suggest that prostate tumors expressing BRCA1 protein carry a more aggressive phenotype, and that BRCA1 expression may be a novel prognostic marker in men with prostate cancer.

The $B R C A 1$ gene codes for a 1,863 base pair protein that is an integral component of the homologous recombination (HR) DNA repair pathway $(18,19)$. The HR pathway uses sequences on homologous sister chromatids as templates to repair DNA double strand breaks with great accuracy (19-21). Inappropriate fusion of double strand breaks can produce chromosomal rearrangements and resultant gene loss, amplification, or fusions that contribute to carcinogenesis (5-7).

While deficiency of functional BRCA1 protein can promote the transformation of benign prostatic epithelium into cancer, subsequent BRCA1 expression in tumor tissue could be indicative of a more aggressive phenotype and portend a worse prognosis. In addition to its role in DNA repair, BRCA1 protein has been shown to be involved in cell cycle checkpoint control (3). The strong association between BRCA1 expression and Ki67 proliferative index found in both the HPFS and PHS analyses raises the possibility that BRCA1 expression may be upregulated in highly proliferative tumors in a futile attempt to check their growth.

However, the fact that adjustment for Ki67 in this analysis did not significantly attenuate the association between BRCA1 and lethal prostate cancer suggests that BRCA1 may promote cancer progression by other mechanisms. For example, it is known that the accelerated replication and growth of cancer cells results in a rapid accrual of double strand breaks that, if not promptly repaired, trigger cancer cell senescence or apoptosis $(6,22,23)$. Overexpression of BRCA1 and other homologous repair pathway components could therefore be an adaptive 
mechanism that confers a survival advantage to the cancer cell by averting double strand breakinduced apoptosis. This hypothesis is in keeping with the strong association between BRCA1 expression and tumor proliferation and apoptosis seen in our study, both of which would be expected to correlate positively with DNA damage stress. A similar phenomenon has been described in patients with non-small cell lung cancer, in whom immunohistochemical expression of the HR pathway component Rad51 has been shown to be an independent predictor of worse survival (24).

In addition to its prognostic significance, BRCA1 expression status may have therapeutic implications. BRCA1 has been shown to modulate chemosensitivity in ovarian, breast, and nonsmall cell lung carcinomas, with tumors expressing BRCA1 being relatively resistant to DNAdamaging agents such as bleomycin, etoposide, and cisplatin, and more sensitive to mitotic inhibitors such as paclitaxel (25-27). Whether the sensitivity of castration-resistant prostate cancers to docetaxel-based chemotherapy differs according to BRCA1 status presents an avenue for exploration. Similarly, because ionizing radiation exerts its tumoricidal effect by inducing DNA damage, radiosensitivity of prostate tumors may likewise differ according to BRCA1 status (28). In the future, tumor BRCA1 expression may also guide therapy with biologics targeting DNA damage response pathways. One such targeted therapy, poly-ADP(ribose) polymerase-1 (PARP1) inhibitors, prevents repair of single stranded DNA breaks, which can progress to double strand breaks. Not surprisingly, cancers in BRCAl mutation carriers have been shown to be particularly sensitive to PARP1 inhibition $(29,30)$, and future use of PARP1 inhibitors in prostate cancer patients may be guided by tumor BRCA1 expression.

This is the largest study to date of BRCA1 expression in prostate cancer, and the first to report an association between BRCA1 expression and apoptotic index. The strengths of the HPFS cohort 
are its prospective design and complete follow-up, allowing us to study lethal prostate cancer as the primary endpoint. The specimens underwent centralized histopathologic review by experienced genitourinary pathologists. The fact that the cohort consists almost exclusively of white professionals could limit generalizability of the findings to the general male population. However, although the prevalence of BRCA1 protein expression may differ by race, it seems unlikely that the biological associations of BRCA1 would differ by socioeconomic status. In summary, BRCA1 protein expression in prostate cancer is strongly correlated with tumor grade and proliferation, and may be an independent predictor of cancer progression. The biological role of BRCA1 in tumor survival as well as the role of BRCA1 expression in guiding prostate cancer therapy deserve further study.

\section{ACKNOWLEDGEMENTS}

We are grateful to the participants and staff of the Health Professionals Follow-up Study for their valuable contributions. In addition we would like to thank the following state cancer registries for their help: AL, AZ, AR, CA, CO, CT, DE, FL, GA, ID, IL, IN, IA, KY, LA, ME, MD, MA, MI, NE, NH, NJ, NY, NC, ND, OH, OK, OR, PA, RI, SC, TN, TX, VA, WA, WY. The DanaFarber/Harvard Cancer Center Tissue Microarray Core Facility constructed the tissue microarrays for this project. We are grateful to Chungdak Li for her expert assistance in constructing the tissue microarrays. 


\section{REFERENCES}

1. Chen JJ, Silver D, Cantor S, Livingston DM, Scully R. BRCA1, BRCA2, and Rad51 operate in a common DNA damage response pathway. Cancer Res. 1999;59:1752s-6s. 2. $\mathrm{Hu}$ YF, Hao ZL, Li R. Chromatin remodeling and activation of chromosomal DNA replication by an acidic transcriptional activation domain from BRCA1. Genes Dev. 1999; 13:637-42.

3. Fabbro M, Savage K, Hobson K, Deans AJ, Powell SN, McArthur GA, et al. BRCA1BARD1 complexes are required for p53Ser-15 phosphorylation and a G1/S arrest following ionizing radiation-induced DNA damage. J Biol Chem. 2004;279:31251-8.

4. Joukov V, Groen AC, Prokhorova T, Gerson R, White E, Rodriguez A, et al. The BRCA1/BARD1 heterodimer modulates ran-dependent mitotic spindle assembly. Cell. 2006;127:539-52.

5. O'Donovan PJ, Livingston DM. BRCA1 and BRCA2: breast/ovarian cancer susceptibility gene products and participants in DNA double-strand break repair. Carcinogenesis. 2010;31:9617.

6. Luo J, Solimini NL, Elledge SJ. Principles of cancer therapy: oncogene and nononcogene addiction. Cell. 2009;136:823-37.

7. Khanna KK, Jackson SP. DNA double-strand breaks: signaling, repair and the cancer connection. Nat Genet. 2001;27:247-54.

8. Ford D, Easton DF, Bishop DT, Narod SA, Goldgar DE. Risks of cancer in BRCA1mutation carriers. Breast Cancer Linkage Consortium. Lancet. 1994;343:692-5.

9. Gao X, Zacharek A, Salkowski A, Grignon DJ, Sakr W, Porter AT, et al. Loss of heterozygosity of the BRCA1 and other loci on chromosome 17q in human prostate cancer. Cancer Res. 1995;55:1002-5.

10. Schayek H, Haugk K, Sun S, True LD, Plymate SR, Werner H. Tumor suppressor BRCA1 is expressed in prostate cancer and controls insulin-like growth factor I receptor (IGFIR) gene transcription in an androgen receptor-dependent manner. Clin Cancer Res. 2009;15:1558-65.

11. Fiorentino M, Judson G, Penney K, Flavin R, Stark J, Fiore C, et al. Immunohistochemical expression of BRCA1 and lethal prostate cancer. Cancer Res. 2010;70:3136-9.

12. Quinn JE, James CR, Stewart GE, Mulligan JM, White P, Chang GK, et al. BRCA1 mRNA expression levels predict for overall survival in ovarian cancer after chemotherapy. Clin Cancer Res. 2007;13:7413-20.

13. Weberpals JI, Tu D, Squire JA, Amin MS, Islam S, Pelletier LB, et al. Breast cancer 1 (BRCA1) protein expression as a prognostic marker in sporadic epithelial ovarian carcinoma: an NCIC CTG OV.16 correlative study. Ann Oncol. 2011;22:2403-10.

14. Yang Q, Sakurai T, Mori I, Yoshimura G, Nakamura M, Nakamura Y, et al. Prognostic significance of BRCA1 expression in Japanese sporadic breast carcinomas. Cancer. 2001;92:5460 .

15. Taron M, Rosell R, Felip E, Mendez P, Souglakos J, Ronco MS, et al. BRCA1 mRNA expression levels as an indicator of chemoresistance in lung cancer. Hum Mol Genet. 2004;13:2443-9. 
16. Pettersson A, Graff RE, Bauer SR, Pitt MJ, Lis RT, Stack EC, et al. The TMPRSS2:ERG rearrangement, ERG expression, and prostate cancer outcomes: a cohort study and meta-analysis. Cancer Epidemiol Biomarkers Prev. 2012;21:1497-509.

17. Mucci LA, Powolny A, Giovannucci E, Liao Z, Kenfield SA, Shen R, et al. Prospective study of prostate tumor angiogenesis and cancer-specific mortality in the health professionals follow-up study. Journal of clinical oncology : official journal of the American Society of Clinical Oncology. 2009;27:5627-33.

18. Miki Y, Swensen J, Shattuck-Eidens D, Futreal PA, Harshman K, Tavtigian S, et al. A strong candidate for the breast and ovarian cancer susceptibility gene BRCA1. Science. 1994;266:66-71.

19. Moynahan ME, Chiu JW, Koller BH, Jasin M. Brca1 controls homology-directed DNA repair. Mol Cell. 1999;4:511-8.

20. Zhong Q, Chen CF, Li S, Chen Y, Wang CC, Xiao J, et al. Association of BRCA1 with the hRad50-hMre11-p95 complex and the DNA damage response. Science. 1999;285:747-50.

21. Huen MS, Sy SM, Chen J. BRCA1 and its toolbox for the maintenance of genome integrity. Nat Rev Mol Cell Biol. 2010;11:138-48.

22. Rich T, Allen RL, Wyllie AH. Defying death after DNA damage. Nature. 2000;407:777-

83.

23. Bartkova J, Rezaei N, Liontos M, Karakaidos P, Kletsas D, Issaeva N, et al. Oncogeneinduced senescence is part of the tumorigenesis barrier imposed by DNA damage checkpoints. Nature. 2006;444:633-7.

24. Qiao GB, Wu YL, Yang XN, Zhong WZ, Xie D, Guan XY, et al. High-level expression of Rad51 is an independent prognostic marker of survival in non-small-cell lung cancer patients. British journal of cancer. 2005;93:137-43.

25. Quinn JE, Kennedy RD, Mullan PB, Gilmore PM, Carty M, Johnston PG, et al. BRCA1 functions as a differential modulator of chemotherapy-induced apoptosis. Cancer Res. 2003;63:6221-8.

26. Wang L, Wei J, Qian X, Yin H, Zhao Y, Yu L, et al. ERCC1 and BRCA1 mRNA expression levels in metastatic malignant effusions is associated with chemosensitivity to cisplatin and/or docetaxel. BMC Cancer. 2008;8:97.

27. Carser JE, Quinn JE, Michie CO, O'Brien EJ, McCluggage WG, Maxwell P, et al. BRCA1 is both a prognostic and predictive biomarker of response to chemotherapy in sporadic epithelial ovarian cancer. Gynecol Oncol. 2011;123:492-8.

28. Jorgensen TJ. Enhancing radiosensitivity: targeting the DNA repair pathways. Cancer Biol Ther. 2009;8:665-70.

29. Shaheen M, Allen C, Nickoloff JA, Hromas R. Synthetic lethality: exploiting the addiction of cancer to DNA repair. Blood. 2011;117:6074-82.

30. Fong PC, Boss DS, Yap TA, Tutt A, Wu P, Mergui-Roelvink M, et al. Inhibition of poly(ADP-ribose) polymerase in tumors from BRCA mutation carriers. N Engl J Med. 2009;361:123-34. 
Running title: BRCA1 protein expression in prostate cancer

Table 1. Patient and tumor characteristics of the HPFS cohort by BRCA1 protein expression

\begin{tabular}{|c|c|c|c|}
\hline & $\begin{array}{c}\text { BRCA1 Negative } \\
\quad(n=529)\end{array}$ & $\begin{array}{c}\text { BRCA1 Positive } \\
(n=60)\end{array}$ & $p$-value \\
\hline $\begin{array}{l}\text { Age at diagnosis (years), } \\
\text { mean }(S D)\end{array}$ & $65.5(6.3)$ & $66.2(5.6)$ & $0.43^{\mathrm{a}}$ \\
\hline $\begin{array}{l}\text { PSA at diagnosis }(n g / m L), \\
\text { median }(\operatorname{IQR})\end{array}$ & $7.2(5.1-11.4)$ & $8.3(4.7-18.5)$ & $0.17^{\mathrm{b}}$ \\
\hline $\begin{array}{l}\text { Follow-up time (years), } \\
\text { median (IQR) }\end{array}$ & $14.3(11.9-17.3)$ & $14.1(9.0-17.5)$ & $0.42^{\mathrm{b}}$ \\
\hline \multicolumn{4}{|l|}{ Gleason score, $n(\%)$} \\
\hline$\leq 6$ & $94(17.8)$ & $6(10.0)$ & $0.01^{\mathrm{c}}$ \\
\hline $3+4$ & $198(37.4)$ & $17(28.3)$ & \\
\hline $4+3$ & $137(25.9)$ & $20(33.3)$ & \\
\hline$\geq 8$ & $100(18.9)$ & $17(28.3)$ & \\
\hline \multicolumn{4}{|l|}{ Pathologic TNM stage ${ }^{e}, n(\%)$} \\
\hline$p T 2$ & $342(68.7)$ & $35(72.9)$ & $0.34^{c}$ \\
\hline$p T 3$ & 139 (27.9) & $13(27.1)$ & \\
\hline$p T 4 / N_{+}$ & $17(3.4)$ & $0(0)$ & \\
\hline Lethal prostate cancer, $n(\%)$ & $59(11.2)$ & $15(25.0)$ & $0.002^{\mathrm{d}}$ \\
\hline
\end{tabular}


Running title: BRCA1 protein expression in prostate cancer

Table 2. Association between BRCA1 protein expression and extent of tumor proliferation, apoptosis, and angiogenesis, Health Professionals Follow-up Study

\begin{tabular}{|c|c|c|c|}
\hline & BRCA1 - & BRCA1 + & $p$-value \\
\hline \multicolumn{4}{|l|}{ Ki67 \% positive nuclei, $n$ (\%) } \\
\hline$Q 10(0)^{a}$ & $159(33.5)$ & $11(19.3)$ & \multirow[t]{4}{*}{$0.005^{\mathrm{e}}$} \\
\hline$Q 20.01-0.11(0.05)$ & $85(17.9)$ & $10(17.5)$ & \\
\hline$Q 3 \quad 0.12-0.45(0.23)$ & $120(25.3)$ & $13(22.8)$ & \\
\hline$Q 4 \geq 0.46(0.95)$ & $110(23.2)$ & $23(40.4)$ & \\
\hline \multicolumn{4}{|l|}{ TUNEL \% positive nuclei, $n(\%)$} \\
\hline$Q 10(0)$ & $124(30.7)$ & $10(21.3)$ & \multirow[t]{4}{*}{$0.03^{\mathrm{e}}$} \\
\hline$Q 20.1-0.5(0.5)$ & $136(33.7)$ & $15(31.9)$ & \\
\hline$Q 3 \quad 0.6-2.0(2.0)$ & $64(15.8)$ & $5(10.6)$ & \\
\hline$Q 4 \geq 2.1(5.0)$ & $80(19.8)$ & $17(36.2)$ & \\
\hline \multicolumn{4}{|l|}{ Angiogenesis parameters } \\
\hline $\begin{array}{l}\text { Microvessel density }{ }^{b} \text { (vessels/hpf), } \\
\text { mean }(95 \% \text { CI) }\end{array}$ & $69.6(66.7,72.7)$ & $72.5(63.2,83.2)$ & $0.59^{\mathrm{f}}$ \\
\hline Vessel diameter, ${ }^{c}(\mu \mathrm{m})$, mean $(95 \% \mathrm{CI})$ & $24.4(24.0,24.9)$ & $24.5(23.1,26.1)$ & $0.91^{\mathrm{f}}$ \\
\hline Vessel area, ${ }^{c}\left(\mu m^{2}\right)$ mean $(95 \% C I)$ & $477(456,499)$ & $481(417,555)$ & $0.91^{\mathrm{f}}$ \\
\hline Lumen irregularity, ${ }^{b}$ mean $(95 \%$ CI) & $3.9(3.8,4.0)^{\mathrm{d}}$ & $4.0(3.7,4.3)$ & $0.64^{\mathrm{f}}$ \\
\hline \multicolumn{4}{|c|}{$\begin{array}{l}Q 1 \text {, first quartile; } Q 2 \text {, second quartile; } Q 3 \text {, third quartile; } Q 4 \text {, fourth quartile; } C I \text {, confidence interval; } h p f \text {, high-power field; } \\
\text { a median value within quartile; }{ }^{\mathrm{b}} \text { higher is more angiogenic; }{ }^{\mathrm{c}} \text { lower is more angiogenic; }{ }^{\mathrm{d}} \text { score of } 1.0 \text { indicates perfectly } \\
\text { circular vessels; }{ }^{\mathrm{e}} p \text {-value derived by chi-square test for trend; }{ }^{\mathrm{f}} \text { general linear model }\end{array}$} \\
\hline
\end{tabular}


Running title: BRCA1 protein expression in prostate cancer

Table 3. Hazard ratios and $95 \%$ confidence intervals of the association between BRCA1 protein expression lethal prostate cancer, Health Professionals Follow-up Study

\begin{tabular}{|c|c|c|}
\hline & HR $(95 \%$ CI $)$ & $p$-value \\
\hline \multicolumn{3}{|l|}{ Univariate } \\
\hline BRCA1 - & Ref. & 0.003 \\
\hline$B R C A 1+$ & $2.40(1.36-4.23)$ & \\
\hline \multicolumn{3}{|l|}{ Multivariate } \\
\hline BRCA1 - & Ref. & 0.053 \\
\hline$B R C A 1+$ & $1.76(0.99-3.11)$ & \\
\hline Age at diagnosis ${ }^{a}$ & $1.14(0.75-1.71)$ & 0.54 \\
\hline \multicolumn{3}{|l|}{ Gleason score } \\
\hline$\leq 6$ & Ref. & $<0.001^{\mathrm{b}}$ \\
\hline $3+4$ & $2.31(0.51-10.53)$ & \\
\hline $4+3$ & $9.21(2.19-38.8)$ & \\
\hline$\geq 8$ & $17.9(4.28-74.7)$ & \\
\hline
\end{tabular}


Running title: BRCA1 protein expression in prostate cancer

\section{Figure legends}

Figure 1. Prostate tumor tissue immunostaining (A) negative and (B) positive for BRCA1.

BRCA1 localizes to the nucleus which is stained brown with DAB. Slides were counterstained with hematoxylin and photographed at a magnification of 200x.
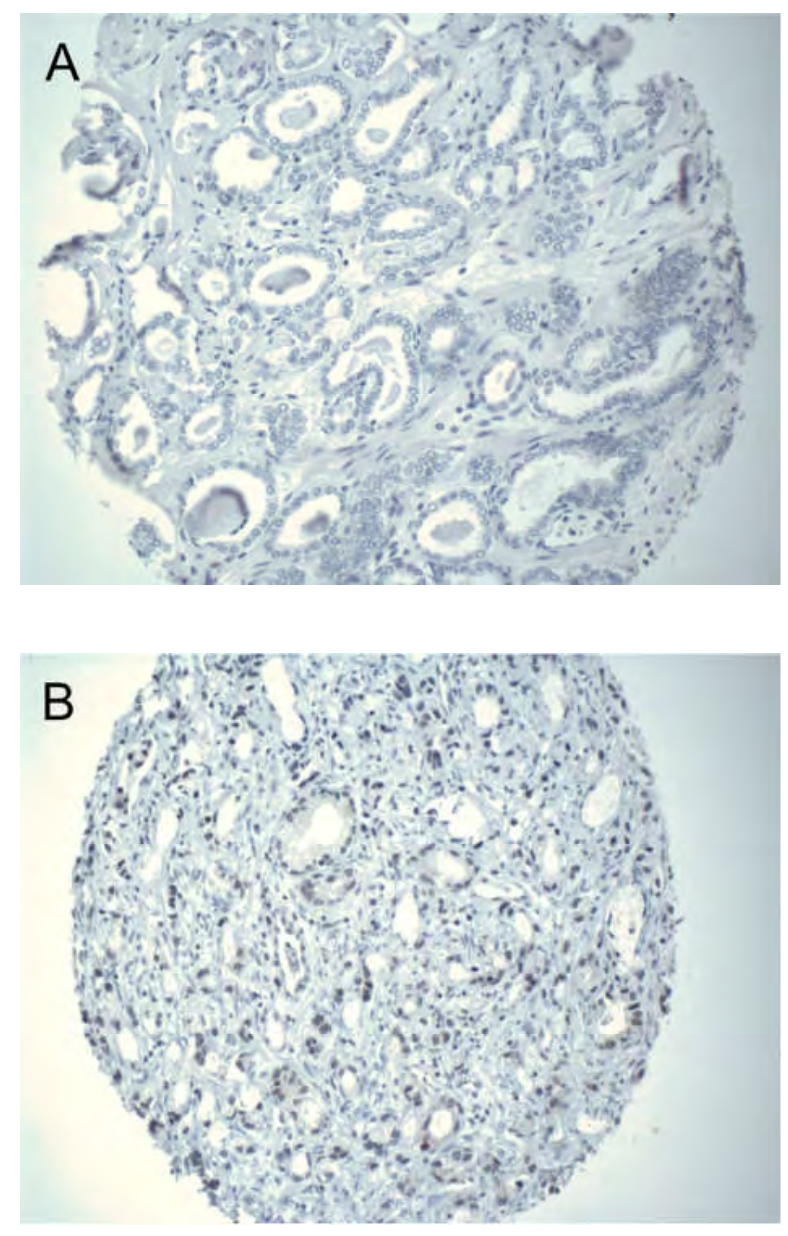


\section{IMMUNOHISTOCHEMICAL EXPRESSION OF BRCA1 AND PROSTATE CANCER PROGRESSION IN A RADICAL PROSTATECTOMY COHORT}

Introduction and Objective: $B R C A 1$ encodes a tumor suppressor protein that plays an important role in repair of DNA double strand breaks. Although $B R C A 1$ mutations are known to promote carcinogenesis, the role of BRCA1 protein in cancer progression and survival is poorly understood. The objective of this study was to determine the association between tumor expression of BRCA1 protein and survival in men with prostate cancer.

Materials and Methods: Immunohistochemical staining for BRCA1 was performed in 589 radical prostatectomy specimens from men participating in the Health Professionals' Follow-Up Study. BRCA1 expression was graded as either present or absent. Tumor proliferation was assessed using immunostaining for Ki67. Study participants were followed prospectively from the date of diagnosis until death or the development of bone or visceral metastases. Proportional hazards regression was used to assess the relationship between BRCA1 expression and lethal prostate cancer.

Results: Immunohistochemical staining was positive for BRCA1 in 60 patients $(10.2 \%)$. There was a strong correlation between BRCA1 expression status and Gleason grade, with BRCA1positive tumors being of higher grade than BRCA1-negative tumors $\left(p_{\text {trend }}=0.01\right)$. Likewise, tumors expressing BRCA1 exhibited a higher proliferative index $\left(p_{\text {trend }}=0.005\right)$. During a median follow-up time of 13.8 years, 58 men (11.0\%) in the BRCA1-negative group and 14 men $(23.3 \%)$ in the BRCA1-positive group developed metastases or died of prostate cancer-related causes. On unadjusted analyses, there was a strong positive association between BRCA1 expression and risk of lethal prostate cancer (HR 2.26, 95\% CI 1.26-4.04, $p=0.006$ ). After adjusting for age at diagnosis and Gleason score, there remained a trend toward a higher risk of 
lethal prostate cancer in BRCA1-positive tumors (HR 1.68, 95\% CI 0.93-3.02, $p=0.08$ ). This association was not significantly attenuated by adjustment for Ki67 proliferative index.

Conclusions: BRCA1 expression in prostate cancer is strongly correlated with tumor grade and proliferative index, and may be an independent predictor of cancer progression. The biological mechanisms by which BRCA1 may promote tumor survival and the role of BRCA1 expression in guiding therapy in patients with castrate-resistant prostate cancer deserve further study. 


\title{
$6^{\text {th }}$ ANNUAL MULTI-INSTITUTIONAL PROSTATE CANCER PROGRAM RETREAT \\ March 18-20, 2013 \\ W Hotel Fort Lauderdale \\ Fort Lauderdale, Florida
}

\author{
Molecular markers associated with altered BRCA1 expression in prostate cancer \\ Travis Gerke, Michelangelo Fiorentino, Dipanjan Choudhury, Andreas Pettersson, Piotr Zareba, Philip Kantoff, \\ Massimo Loda, Stephen Finn, Lorelei Mucci
}

Using data from two large prospective cohorts, our group recently reported associations between presence of BRCA1 protein expression in prostate tumor tissue and higher Gleason grade, substantially increased tumor proliferation index, and greater risk of lethal cancer. These findings are seemingly in contrast to evidence that deficiencies in the tumor suppressor and DNA repair protein BRCA1 are implicated in breast tumorigenesis. Further research is needed to elucidate the biological nature of aberrant BRCA1 expression and its participation in prostate cancer progression. We hypothesized that the integration of mRNA expression with BRCA1 protein expression in prostate tumor tissue may help guide such investigations.

The present study utilizes existing gene expression profiling data of 6096 genes from archival prostate tumor tissue for 116 men in the Physicians' Health Study who were predominately treated with radical prostatectomy. Among this group, 91 had been characterized immunohistochemically for BRCA1 protein, which was graded as present or absent by dedicated study pathologists. Increased risk of lethal prostate cancer for high BRCA1 was corroborated at the mRNA level, with each standard deviation increase in expression yielding an odds ratio of 2.23 (95\% CI 1.39-3.86, p=0.002) for lethal disease. Expression levels for each of the 6096 genes assayed were evaluated for association with the presence of BRCA1 protein using a genewise linear modeling approach. Although BRCA1 mRNA expression was correlated with BRCA1 positive staining ( $\mathrm{p}=0.03), 420$ genes exhibited a stronger association. Eight genes (NR4A1, BCL3, HPN, BMP6, EGR1, BTG2, FOS, and HIPK2) maintained a significant relationship (FDR $\mathrm{q}<0.05$ ) after adjustment for multiple testing. Gene set analyses were also performed using the 186 available KEGG pathways from the Broad's Molecular Signatures Database. The top 5 ranking pathway-level associations included cell cycle, DNA replication, regulation of autophagy, NOD-like receptor signaling, and progesterone-mediated oocyte maturation.

Taken together, the mRNA associations with BRCA1 protein expression support previous hypotheses that BRCA1 may relate to prostate cancer survival through participation in cell cycle control and, in particular, IGF signaling. Notably, IGF has been linked to BMP6 and FOS expression in osteogenic environments, suggesting one possible postulate for increased bone metastases incidence in men with BRCA1 positive tumors. 